\title{
Estimating Pollution Loads in Snow Removed from a Port Facility: Snow Pile Sampling Strategies
}

\author{
Arya Vijayan (1D • Heléne Österlund • Jiri Marsalek • \\ Maria Viklander
}

Received: 14 October 2020 / Accepted: 13 January 2021 /Published online: 12 February 2021

(C) The Author(s) 2021

\begin{abstract}
Choosing the appropriate sampling strategy is significant while estimating the pollutant loads in a snow pile and assessing environmental impacts of dumping snow into water bodies. This paper compares different snow pile sampling strategies, looking for the most efficient way to estimate the pollutant loads in a snow pile. For this purpose, 177 snow samples were collected from nine snow piles (average pile area $-30 \mathrm{~m}^{2}$, height $-2 \mathrm{~m}$ ) during four sampling occasions at Frihamnen, Ports of Stockholm's port area. The measured concentrations of TSS, LOI, pH, conductivity, and heavy metals ( $\mathrm{Zn}, \mathrm{Cu}$, $\mathrm{Cd}, \mathrm{Cr}, \mathrm{Pb}$, and $\mathrm{V}$ ) in the collected samples indicated that pollutants are not uniformly distributed in the snow piles. Pollutant loads calculated from different sampling strategies were compared against the load calculated using all samples collected for each pile (best estimate of mass load, BEML). The results/study showed that systematic
\end{abstract}

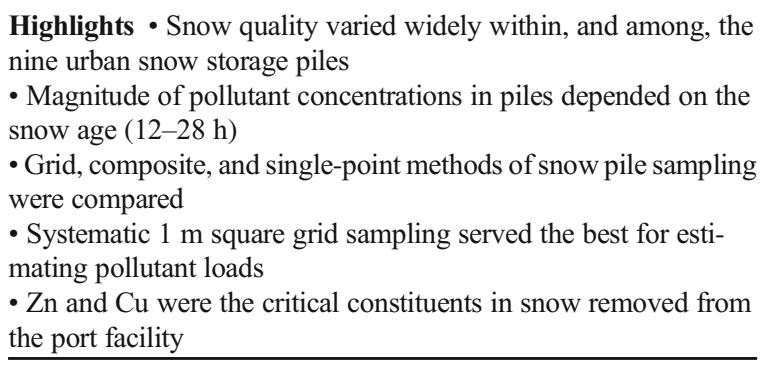

A. Vijayan $(\bowtie) \cdot$ H. Österlund $\cdot$ J. Marsalek $\cdot$ M. Viklander Department of Civil, Environmental and Natural Resources Engineering, Luleå University of Technology, 97187 Luleå, Sweden

e-mail: arya.vijayan@ltu.se grid sampling is the best choice when the objective of sampling is to estimate the pollutant loads accurately. Estimating pollutant loads from single snow column samples (collected at a point from the snow pile through the entire depth of the pile) produced up to $400 \%$ variation from BEML, whereas samples composed by mixing volume-proportional subsamples from all samples (horizontal composite samples) produced only up to $50 \%$ variation. Around nine samples were required to estimate the pollutant loads within 50\% deviation from BEML for the studied snow piles. Converting pollutant concentrations in snow to equivalent concentrations in snowmelt and comparing it with available guideline values for receiving water, $\mathrm{Zn}$ was identified as the critical pollutant.

Keywords Mass load Pollutants in urban snow · Snow disposal in water $\cdot$ Snow pile sampling $\cdot$ Sampling strategies $\cdot$ Systematic grid sampling

\section{Introduction}

Cities in cool temperate climate regions face challenges in managing and disposing millions of tons of snow fallen during winter months (ADEC 2006). Toward this end, municipalities develop and implement snow and ice control plans, which specify the levels of service and the associated needs of resources (City of Toronto 2019). Most of these activities are within the jurisdiction of local authorities, except for snow disposal, which may cause environmental impacts on local water resources. There are several options for the disposal of 
snow: (a) removal of used snow to local storage sites (Reinosdotter and Viklander 2006), where it melts and the resulting snowmelt is discharged on land, or into the municipal drainage system; (b) snow removal to central snow storage sites, which usually provide some level of snowmelt treatment, e.g., by settling in a pond (Exall et al. 2011); and (c) dumping of removed snow into open water bodies (Marsalek et al. 2003).

To provide guidance for choosing among the disposal methods, a number of studies have been carried out, focusing on environmental impacts of different methods (e.g., Viklander 1997; Oberts et al. 2000). In situ melting on directly connected impervious surfaces (e.g., on parking lots of commercial plazas) leads to snowmelt entry into storm sewers and conveyance to the receiving waters. During the melting, dissolved substances (e.g., chloride) leave the snow pile early (Schondorf and Herrmann 1987), but sediment residue stays on the ground and is mechanically removed in early spring (Viklander 1996; Viklander 1997; Vijayan et al. 2019). Thus, in situ melting provides some form of treatment of snowmelt, resulting in removal of coarse solids with adsorbed pollutants. Snow disposal on land differs from the preceding case with respect to the fate of dissolved pollutants - they may either infiltrate into the ground or be transported with surface runoff (Malmquist 1984). Infiltrating pollutants may pollute shallow groundwater (e.g., chloride, Environment Canada and Health Canada 2000) and also negatively impact on soils, their cover, structure, infiltration capacity (Trahan and Peterson 2007) and fertility, and surrounding lands (Lobkina et al. 2019; Minigazimov et al. 2019). However, with proper design, these impacts can be mitigated, and on-land snow disposal is currently considered as the best management practice in snow disposal (Lindqvist 2019), when environmental effects of snow transportation (traffic, noise) can be managed.

The last mentioned method of snow disposal, direct dumping into open waters, delivers the full load of pollutants contained in a snow deposit to the receiving waters, without any form of treatment (Reinosdotter and Viklander 2006). Consequently, routine direct disposal of urban snow in fresh or marine waters is prohibited in most jurisdictions, but exceptions may be permitted by environmental agencies in emergency situations of extreme snowfalls and no space for snow storage. These exceptions may be conditional on limiting the potential pollution loads contained in dumped snow, e.g., by dumping only fresh snow, or snow from less polluted areas. In any case, determination of pollutant loads delivered to the receiving waters is a key factor in protecting such waters and planning control measures. Estimation of pollutant load in urban snow is a complex task, because of large variation of pollutant concentrations in snow piles (Droste and Johnston 1993). Therefore, selecting an effective strategy for sampling snow piles is fundamental in estimating pollutant loads.

Even though it may appear that sampling of polluted snow is similar to sampling contaminated soils or sediments, there are also differences among such media, particularly with respect to downward vertical transport of pollutants or contaminants. The earlier mentioned preferential elution of dissolved substances from snow, which can be triggered by intermittent snowmelts, may contribute to a greater stratification of such substances in the snow pile. Thus, effective sampling of snow should address variability of snow quality in space. In the horizontal plane, this is best accomplished by a systematic grid sampling (Malherbe 2002; Fabietti et al. 2010) and, in the vertical direction, by collecting samples composited along the vertical (Lovison et al. 1994; Vallero 2013).

Many researchers studied concentrations of pollutants in urban snow (Malmquist 1978; Jervis et al. 1982; Viklander 1999; Reinosdotter and Viklander 2005; Sillanpää and Koivusalo 2013; Kuoppamäki et al. 2014; Siudek et al. 2015) and/or assessed the environmental impacts of snow disposal into the receiving waters (Novotny et al. 1998; Engelhard et al. 2007; Corsi et al. 2010). However, none of those studies addressed the sampling of urban snow piles for a robust estimation of stored pollutant loads. The primary objectives of our study were threefold: (a) assess the pollutant loads (total suspended solid (TSS), trace metals, PAHs) in piles holding snow cleared from a port area, (b) assess the accuracy of load estimates depending on the number of samples collected, and (c) assess the observed pollutant concentrations in the context of the available guideline values.

\section{Materials and Methods}

\subsection{Study Area}

Snow samples were collected during the winters 2016/ 2017 and 2017/2018 from a commercially prominent port area of Stockholm, Frihamnen (Fig. 1). About half of the international cruise arrivals to Stockholm take place at Frihamnen. The catchment area of the Frihamnen port is 

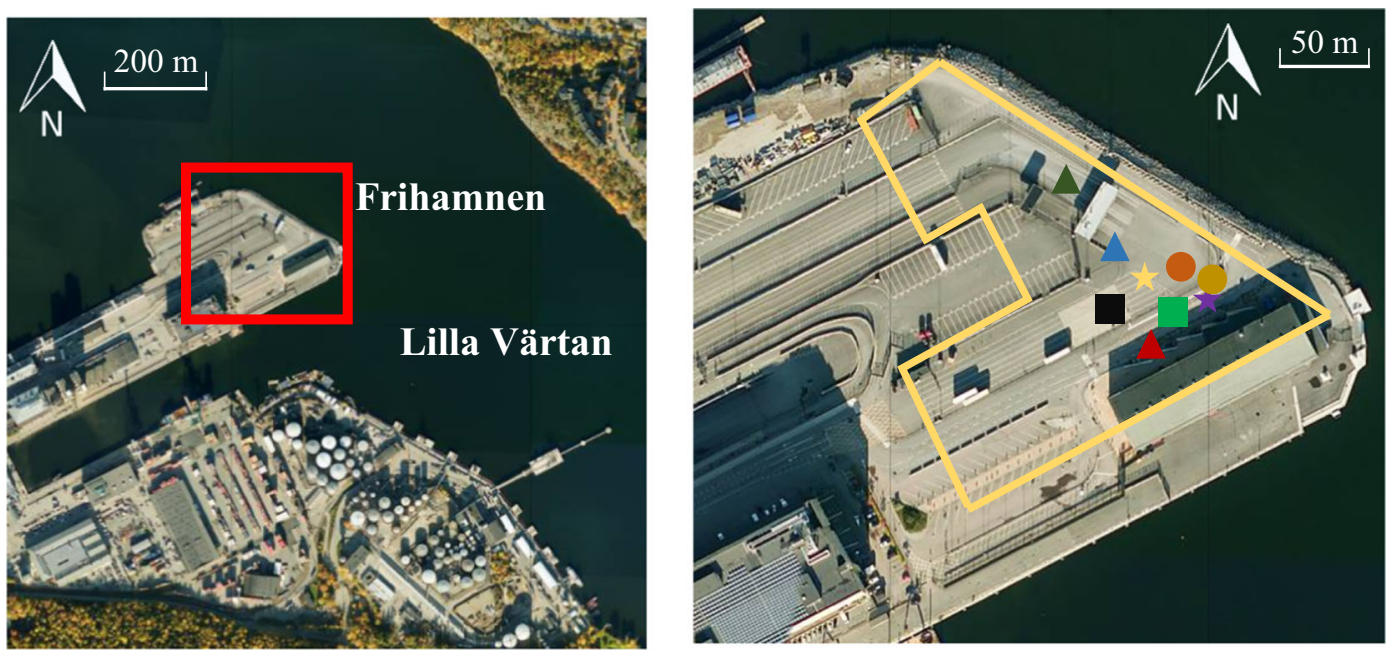

Pile A- $\Delta$ Pile B- $\Delta$ Pile C- $\Delta$ Pile D- $\boldsymbol{a}$ Pile E- - Pile F- $\star$ Pile G- $\star$ Pile H- $\bullet$ Pile I- $\bullet$ (The marking are not up to scale)

Fig. 1 Map of the study area in Frihamnen (59 $20^{\prime} 41^{\prime \prime} \mathrm{N}$ and $18^{\circ} 7^{\prime} 36^{\prime \prime} \mathrm{E}$, Stockholm, Sweden) showing the sampled snow piles and the receiving water body Lilla Värtan. The port catchment boundaries are indicated by the yellow line

1.8 ha and consists of paved asphalt surfaces (roads and parking lots), with less than $1 \%$ of the area attributed to rooftops. The catchment is served by a separate sewer system, with separate treatment facilities for wastewater and stormwater. The stormwater and snowmelt runoff from the catchment passes through a treatment train consisting of a flow control chamber limiting the flow to the downstream treatment units (ACO NORDIC 2013a) comprising a sludge trap separating sand and sludge (ACO NORDIC 2013b) and an oil separator (ACO NORDIC 2018a, b). The treated effluent is discharged into a marine strait Lilla Värtan, covering an area of $13 \mathrm{~km}^{2}$ (Fig. 1). After a snowfall, the snow is plowed, temporarily stored in piles, and, because of the lack of space, dumped into Lilla Värtan as soon as possible.

The winter onset in Sweden is defined as the first of the five consecutive days with daily mean temperature below $0{ }^{\circ} \mathrm{C}$. In Stockholm, winter starts usually in December and lasts until February. According to the Swedish Meteorological and Hydrological Institute (SMHI 2020), Stockholm gets on average about 170 days with precipitation in a year, and during the study period, the average annual precipitation was $450 \mathrm{~mm}$, including $90 \mathrm{~mm}$ of snow. The annual average temperature in Stockholm is about $8^{\circ} \mathrm{C}$, and the coldest month is January, with average monthly temperature of $-1{ }^{\circ} \mathrm{C}$.
In Sweden, snow is considered as a solid waste and its disposal into surface water bodies is generally not permitted (The Swedish Environmental Code, 1999). However, the county administrative board has issued a permit for dumping of snow, with a number of conditions, including that the Stockholm Port Authority shall investigate the environmental impacts of snow dumping. Limited data on water and sediment quality is available for Lilla Värtan. The ecological and chemical status of Lilla Värtan was classified as "Unsatisfactory" by the Water Information System Sweden (VISS EU_CD: SE658352-163189 2019) as elaborated later.

\subsection{Sampling Methods}

On 11 November 2016, snow samples were collected using a 1-m-long titanium ice drill with a $12 \mathrm{~cm}$ diameter. Sampling holes were drilled at 1-m intervals in a square grid centered over the bases of snow piles, of which shape was similar to that of a truncated elliptical cone. Because of equipment limitations, some samples (37 out of 177) were collected only from the top 1-m layer of the piles having the height greater than $1 \mathrm{~m}$. Those samples did not represent the whole vertical profile of the snow pile, since concentrations of pollutants in snow vary with depth (Henriksen et al. 1974; 
Johannessen and Henriksen 1978; Novotny et al. 1999). After drilling the hole, snow from the hole was collected and placed in a plastic bag. The diameter and depth of the sampling hole were measured and recorded. This was repeated for all the piles.

During 2018, snow samples were collected with a snow column sampler made of Lexan, which is a polycarbonate resin thermoplastic of a high impact strength. The sampler was $1.5 \mathrm{~m}$ long, with a diameter of $5 \mathrm{~cm}$. It also had a cutter head with aggressive teeth for cutting through snow. Samples were collected from snow piles in a 1-m grid pattern. After cutting through the pile, the sampler holding the snow sample was emptied into a plastic bag. Where pile depths exceeded $1.5 \mathrm{~m}$, the samples were collected first from the top $1.5 \mathrm{~m}$, then snow from the top pile part was removed, and the bottom part of the pile was also sampled. The slopes of piles were calculated from the height of snow columns and the distance between sampling points. The plastic bags with snow samples were labeled, placed in insulated coolers with freezer blocks to prevent sample melting, and transported to the laboratory, where they were stored in climate rooms at $-10{ }^{\circ} \mathrm{C}$. The details of collected samples are summarized in Table 1.

\subsection{Sampling Design}

In this study, three types of sampling designs were applied and compared: (i) single snow column sampling, (ii) systematic grid sampling, and (iii) horizontally composed sampling based on collecting two composite samples per pile (Fig. 2). The single snow column samples represent the vertically composed snow core samples collected at any point of the snow pile, through the whole depth of the pile at that point. In systematic grid sampling, the single column snow samples (e.g., 34 in total, in Fig. 2) were collected at regular intervals in a systematic manner, following a 1-m square grid pattern. The snow column sample in the middle of the grid square was assumed to have the same snow properties as the corresponding square. The horizontal composite sampling produced two composite samples, one for each half of the pile, and the composite samples comprised snow volume-proportional subsamples of single point samples within the corresponding pile half (see Fig. 2). Examples of these sampling designs are shown in Fig. 2, where the composite sample Comp 1 is produced by composing volume-proportional subsamples from 17 single snow column samples in the left half of the snow pile and Comp 2 sample is composed from the 17 single snow column samples in the right half of the pile. The samples used in producing composite samples for individual piles are shown in online resource Table 1 .

\subsection{Chemical Analyses}

The collected snow samples were melted in Teflon-lined glass beakers at room temperature. Total suspended solids (TSSs), loss on ignition (LOI), $\mathrm{pH}$, and

Table 1 Frihamnen snow sample descriptions

\begin{tabular}{|c|c|c|c|c|c|c|c|}
\hline $\begin{array}{l}\text { Sampling } \\
\text { date }\end{array}$ & $\begin{array}{l}\text { Reported depth of snowfall at } \\
6: 00 \text { am on the sampling date }(\mathrm{cm})^{\text {a }}\end{array}$ & $\begin{array}{l}\text { No. of } \\
\text { piles } \\
\text { sampled }\end{array}$ & $\begin{array}{l}\text { Pile } \\
\text { designation }\end{array}$ & $\begin{array}{l}\text { No. of } \\
\text { samples per } \\
\text { pile }\end{array}$ & $\begin{array}{l}\text { Size of the } \\
\text { pile }^{c}(m)\end{array}$ & $\begin{array}{l}\text { Average slope } \\
\text { of piles }(\%)\end{array}$ & $\begin{array}{l}\text { Age of sampled } \\
\text { snow (hours) }\end{array}$ \\
\hline \multirow[t]{3}{*}{11 Nov 2016} & \multirow[t]{3}{*}{39} & \multirow[t]{3}{*}{3} & Pile $A^{b}$ & 9 & $5 \times 5 \times 2$ & $\mathrm{n} / \mathrm{a}^{\mathrm{d}}$ & \multirow{3}{*}{17} \\
\hline & & & Pile $B^{b}$ & 11 & $9 \times 3 \times 1.5$ & $\mathrm{n} / \mathrm{a}$ & \\
\hline & & & Pile $C^{b}$ & 17 & $9 \times 9 \times 4$ & $\mathrm{n} / \mathrm{a}$ & \\
\hline \multirow[t]{2}{*}{17 Jan 2018} & 7 & 2 & Pile D & 38 & $5 \times 7 \times 1.6$ & 22 & \multirow[t]{2}{*}{20} \\
\hline & & & Pile E & 24 & $5 \times 5 \times 1.6$ & 14 & \\
\hline \multirow[t]{2}{*}{27 Feb 2018} & 15 & 2 & Pile F & 14 & $4 \times 4 \times 1.6$ & 55 & \multirow[t]{2}{*}{28} \\
\hline & & & Pile G & 21 & $6 \times 4 \times 2.1$ & 56 & \\
\hline \multirow[t]{2}{*}{28 Feb 2018} & 18 & 2 & Pile H & 15 & $5 \times 3 \times 1.5$ & 55 & \multirow[t]{2}{*}{12} \\
\hline & & & Pile I & 28 & $7 \times 4 \times 1.7$ & 40 & \\
\hline
\end{tabular}

\footnotetext{
${ }^{a}$ https://www.smhi.se

${ }^{\mathrm{b}}$ Samples were collected only from the top 1-m layer of the pile

${ }^{\mathrm{c}}$ Length $\times$ width $\times$ height $(\mathrm{m})$

${ }^{\mathrm{d}}$ Calculation of slope was not possible since the samples were taken only from the top layer of snow piles
} 


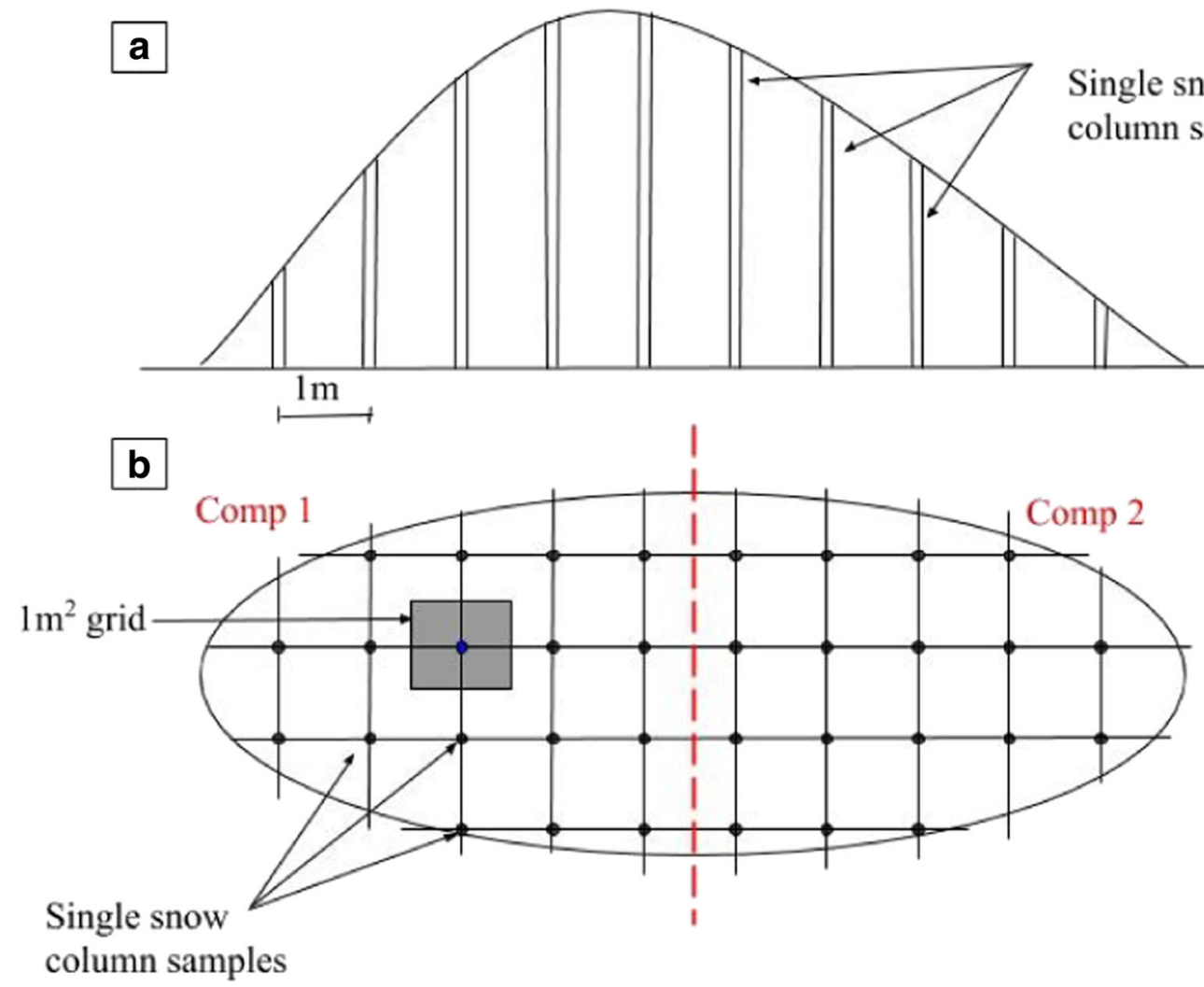

Fig. 2 Three types of sampling design: single snow column sampling, systematic grid sampling, and horizontal composite sampling. Top figure a depicts a cross-section through the center of the snow pile and $\mathbf{b}$ is a plan view of the snow pile

conductivity analyses of all samples were done at the Environmental Laboratory of Luleå University of Technology. The volumes of individual melted snow samples were measured and the total volume of melted snow $\left(V_{\text {tot }}\right)$ was calculated. Subsequently, volume $V_{\text {tot }}$ proportional subsamples were separated from each sample and combined into a single vertically composed sample. Such samples from each pile were split into two groups, each of which represented one-half of the corresponding pile footprint. The samples within each group were composed together to make one horizontal composite sample for each half of the pile. For pile $H$, only one composite sample was made, because there was not enough meltwater available to make two composite samples. PAHs and total and dissolved metals were analyzed for all the composite samples by an accredited commercial laboratory, ALS Scandinavia AB. The samples collected during winter 2017-2018 were analyzed in the same way as the samples from winter 2016-2017, but total and dissolved metal analyses were carried out on all the samples.
TSS was determined by the method described in EN 872:2005 (SS EN 872 2005) with a slight modification by screening the melted snow samples through a 0.5 $\mathrm{mm}$ sieve before the TSS analysis. This pre-screening is not a part of the standard TSS method EN 872:2005, but it was applied to suppress overestimation of TSS caused by gravel particles in snow samples. This modification was further justified by earlier studies (Nordqvist et al. 2011) showing that most particles in the snow and snowmelt samples were below $0.5 \mathrm{~mm}$. After screening, the melted snow was filtered through a pre-dried glass microfiber filter of size $1.6 \mu \mathrm{m}$ (Whatman GF/A glass microfiber filter) using vacuum-assisted filtration. The filter with residue was dried in an oven at $105 \pm 2{ }^{\circ} \mathrm{C}$ for about $3 \mathrm{~h}$ and the filter with dry residue was weighed using an analytical balance with a precision of $0.00001 \mathrm{~g}$. Then, the filter with the residue was placed in a furnace at $550{ }^{\circ} \mathrm{C}$ for $1 \mathrm{~h}$ and weighed using the same balance, and LOI was calculated by dividing the difference between dry sample weight and ignited sample weight by the dry sample weight as specified in SS 
EN 15935:2012 method. Measurements of $\mathrm{pH}$ at room temperature were done using the $\mathrm{pH} 330$ WTW SigmaAldrich instrument with an accuracy of $0.01 \mathrm{pH}$ unit, and, for conductivity measurements, the Radiometer Analytical CDM210 conductivity meter with an accuracy of $\pm 0.2 \%$ of the reading was used.

The total and dissolved metals were analyzed using inductively coupled plasma sector field mass spectrometry (ICP SFMS; SS EN ISO 17294-1, 2) and the US EPA method 200.8. The reporting limits for total metals were as follows: $\mathrm{Zn}, 4 \mu \mathrm{g} / \mathrm{l} ; \mathrm{Cu}, 1 \mu \mathrm{g} / \mathrm{l} ; \mathrm{Cd}, 0.05 \mu \mathrm{g} / \mathrm{l}$; Cr, $0.9 \mu \mathrm{g} / \mathrm{l} ; \mathrm{Pb}, 0.5 \mu \mathrm{g} / \mathrm{l} ; \mathrm{Ni}, 0.6 \mu \mathrm{g} / \mathrm{l}$; and $\mathrm{V}, 0.2 \mu \mathrm{g} / \mathrm{l}$. The reporting limits for dissolved metals were as follows: $\mathrm{Zn}, 0.2 \mu \mathrm{g} / \mathrm{l} ; \mathrm{Cu}, 0.1 \mu \mathrm{g} / \mathrm{l} ; \mathrm{Cd}, 0.002 \mu \mathrm{g} / \mathrm{l} ; \mathrm{Cr}$, $0.01 \mu \mathrm{g} / \mathrm{l} ; \mathrm{Pb}, 0.01 \mu \mathrm{g} / \mathrm{l} ; \mathrm{Ni}, 0.05 \mu \mathrm{g} / \mathrm{l}$; and $\mathrm{V}, 0.005 \mu \mathrm{g} /$ 1 .

The composite samples also were analyzed for the 16 US EPA PAHs: naphthalene (Nap), acenaphthene (Ace), acenaphthylene (Acy), fluorene (Flu), phenanthrene (Phe), anthracene (Ant), fluoranthene (Flt), pyrene (Pyr), benzo[a]anthracene (BaA), chrysene ( Chr), benzo[b]fluoranthene (BbF), benzo[k]fluoranthene $(\mathrm{BkF})$, benzo[a]pyrene $(\mathrm{BaP})$, indeno[1,2,3]pyrene (IndP), dibenzo[a,h]anthracene (DahA), and benzo[ghi]perylene (BghiP). The US EPA 8270 and CSN EN ISO 6468 methods were used for PAH measurements. The reporting limits for these PAHs were as follows: Nap, $0.03 \mu \mathrm{g} / 1$; Phe, $0.02 \mu \mathrm{g} / \mathrm{l}$; and Ace, Acy, Flu, Ant, Flt, Pyr, BaA, Chr, BbF, BkF, $\mathrm{BaP}$, IndP, DahA, and BghiP, all $0.01 \mu \mathrm{g} / \mathrm{l}$.

2.5 Algorithm to Estimate the Mass Load of Pollutants in a Snow Pile

Mass load of a pollutant $p\left(\mathrm{ML}_{\mathrm{p}}\right)$ in a snow pile is calculated using Eq. 1 (Viklander 1999; Reinosdotter and Viklander 2005). Snow water equivalent (SWE) is an important property of snow, equal to the depth of water resulting from melting an entire snow column, and is calculated using Eq. 2 (Semadeni-Davies, 1999).

$M L_{p}=\sum_{i=1}^{N} A_{i} S W E_{i} C p_{i}$

$S W E=\frac{\rho_{s}}{\rho_{w}} H$
$\mathrm{ML}_{\mathrm{p}} \quad$ Mass load of pollutant $p(\mathrm{~g})$

$A_{\mathrm{i}} \quad$ Area (footprint) represented by an individual sample $i\left(\mathrm{~cm}^{2}\right)$

SWE Snow water equivalent $(\mathrm{cm})$

$C_{\mathrm{p}} \quad$ Concentration of pollutant $p$ in the individual sample $i\left(\mathrm{~g} / \mathrm{cm}^{3}\right)$

$N \quad$ Total number of sampling points in the pile footprint

$\rho_{\mathrm{S}} \quad$ Snow density $\left(\mathrm{g} / \mathrm{cm}^{3}\right)$

$\rho_{\mathrm{w}} \quad$ Density of water $\left(\mathrm{g} / \mathrm{cm}^{3}\right)$

$H \quad$ Height of snow column corresponding to sample $i(\mathrm{~cm})$

The challenging part of these calculations is estimating $C_{\mathrm{p}}$ from various samples collected in the sampling grid. For simplification, all samples were assumed to bear the same weight, even though some of them represented somewhat smaller snow volumes along the pile edges.

Load calculations were accomplished by a simple algorithm, which was developed for this study in the python computer language and used to estimate the mass loads of selected pollutants, as schematically shown Fig. 3. The algorithm calculates the mass load of the selected pollutant in a snow pile using all possible combinations of various numbers of samples (i.e., the sampling points). The best estimate of the mass load (BEML) of a particular pollutant in a snow pile is defined here as the estimate based on all the grid samples available. Furthermore, the algorithm calculates mass loads of all pollutants using various numbers of sample combinations and finds the sample combinations, which produce a mass load closest to, and furthest from, BEML. Such mass loads were designated as CEML and FEML, respectively. The BEML was then used to determine the sample combinations producing the least and the maximum deviations from BEML using Eq. 3.

Percentage deviation $=\frac{\left|M L_{i}-B E M L\right|}{B E M L} * 100$

MLi Pollutant mass load (g) estimate with " $i$ ” samples

BEML Best estimate of mass load (g)

The algorithm also gives the mass load calculated from the concentration of pollutants in composite samples. To determine whether the sampling point location affects calculations of the mass loads of pollutants, a 


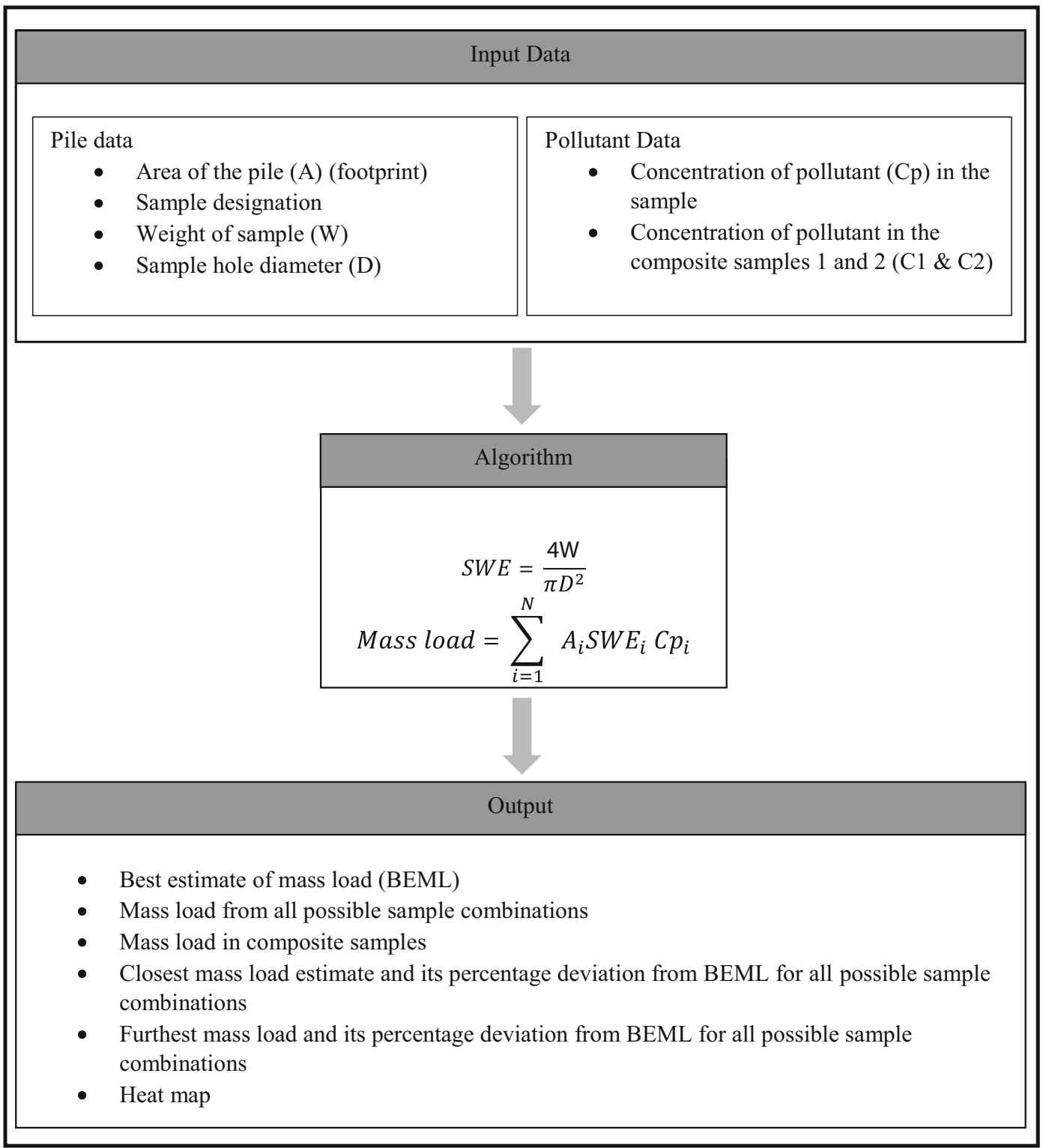

Fig. 3 Algorithm input/output description

heat map was generated for all the piles and serves to visualize the deviation of mass load of a pollutant from BEML, calculated at individual locations.

\subsection{Selection of Snow Quality Parameters}

The environmental impact of snow disposal on the receiving water body depends on the quality of the snow disposed and the sensitivity of the receiving water body (Westerlund et al. 2011). In the absence of receiving water data, the risk of environmental impact can be estimated by calculating the ratio of the measured pollutant concentration to some reference values, which were defined here as the environmental quality standard guidelines. For easy referencing, a risk coefficient was introduced here (Eq. 4) and used for a general assessment of environmental relevance of the measured values (Swedish EPA 5050 2000):

Risk coefficient $=\frac{\text { Measured value }}{\text { Reference value }}$ 
The risk coefficient (RC) is a practical tool for preliminary screening of the quality of fresh snow (respectively of its snowmelt) and indicates some measure of the potential anthropogenic impacts on the receiving waters. Since there are no guidelines available for snow quality, the concentrations of pollutants in snow were converted to equivalent concentrations in the snowmelt using Eqs. 5-7.

$$
\begin{aligned}
& C e q_{p \text { meam }}=\frac{M_{p}}{V_{\text {tot }}} \\
& M_{p}=A_{s a} \sum_{i=1}^{N}\left(S W E_{i} * C p_{i}\right) \\
& \mathrm{V}_{\text {tot }}=A_{s a} * \sum_{i=1}^{N} S W E_{i}
\end{aligned}
$$

$\begin{array}{ll}C_{\mathrm{p}} & \begin{array}{l}\text { Equivalent mean concentration of pollutant } \mathrm{p} \\ \text { mean }\end{array} \\ M_{\mathrm{p}} & \begin{array}{l}\text { Total mass of pollutant } \mathrm{p} \text { in the snow pile } \\ (\mathrm{mg})\end{array} \\ V_{\text {tot }} & \text { Total volume of water in the pile }(\mathrm{l}) \\ A_{\mathrm{sa}} & \text { Area represented by a sampling core }\left(1 \mathrm{~m}^{2}\right) \\ \mathrm{SWE} & \text { Snow water equivalent }(\mathrm{cm}) \\ C_{\mathrm{p}} & \begin{array}{l}\text { Concentration of pollutant } \mathrm{p} \text { in the snow pile } \\ \left(\mathrm{g} / \mathrm{cm}^{3}\right)\end{array} \\ N & \text { Total number of samples in a pile }\end{array}$

\section{Results}

\subsection{The Quality and Heterogeneity of Snow Samples}

This section includes the comparison of quality (described by TSS, LOI, conductivity, heavy metals, and PAHs) of 177 snow samples collected from nine snow piles. The maximum, minimum, and mean values of TSS, LOI, pH, conductivity, and density of each pile are shown in Table 2. TSS, LOI, conductivity, and density reached the highest values in piles F and $G$, which had the longest snow residence time (SRT). The pollutant concentrations showed high positive correlations with SRT. The Pearson correlation coefficients between SRT and various pollutants in snow samples were as follows: TSS, 0.92; $\mathrm{Zn}, 0.94 ; \mathrm{Cu}, 0.80 ; \mathrm{Cd}$, 0.96; Cr, 0.91; $\mathrm{Pb}, 0.96$; and $\mathrm{V}, 0.91$.
In order to compare spatial heterogeneity of different piles, in the x-y plane, the coefficients of variation (CV) were calculated for individual piles, based on quality data at the corresponding sampling points, and presented in Table 2. Pile $\mathrm{H}$ has the highest CV for TSS, LOI, and conductivity, while pile G has the lowest CV for the same parameters, implying that pile $\mathrm{H}$ is the most heterogeneous and pile $\mathrm{G}$ is the most homogeneous among all the sampled piles. The port catchment consists of trafficked and non-trafficked areas, which cause the quality of snow from various areas to differ. One could hypothesize that snow in pile $G$ may have been cleared from the same catchment sub-area, making it homogenous, but pile $\mathrm{H}$ may have received snow from different areas of the catchment, making it heterogeneous. The maximum, minimum, and mean concentrations of $\mathrm{Cd}, \mathrm{Cr}, \mathrm{Cu}, \mathrm{Pb}$, $\mathrm{V}$, and $\mathrm{Zn}$ in all the piles are presented in Table 3. For piles $\mathrm{A}, \mathrm{B}$, and $\mathrm{C}$, these metals were analyzed only in the laterally composited samples, while for piles D, E, F, G, $\mathrm{H}$, and I, the metals were analyzed in all the samples. All the presented metals reached the highest concentrations in piles $\mathrm{F}$ and $\mathrm{G}$ and the lowest concentrations in piles $\mathrm{H}$ and I, except for $\mathrm{Cu}$. The lowest concentrations of $\mathrm{Cu}$ were observed in piles $\mathrm{D}$ and $\mathrm{E}$. The variance described by $\mathrm{CV}$ was particularly high in pile $\mathrm{H}$, illustrating that this pile was the most heterogeneous.

The concentrations of sums of 16 PAHs, carcinogenic PAHs, low-molecular-weight (LMW) PAHs, mediummolecular-weight (MMW) PAHs, and high-molecularweight (HMW) PAHs for composite samples from all the piles are shown in Table 4. Concentrations of Ant PAH are also presented in Table 4, since the concentrations of Ant in the receiving water sediment have been reported to exceed the guideline value (VISS EU_CD: SE658352-163189 2019). However, in most of the snow samples, Ant concentrations were below the reporting limit $(<0.01 \mu \mathrm{g} / \mathrm{l})$. Flt and Pyr were occurring in high concentrations in all the piles. Reinosdotter et al. (2006) studied the quality of snow collected along a highway with traffic intensity of 9200 vehicles/day in Luleå, Sweden, and reported that Flt and Pyr had the highest concentrations in the studied snow samples. The same was reported by Björklund et al. (2011) when examining snow samples collected from three sites with different traffic intensities (500, 59,000, and 90,000 vehicles/day) in Gothenburg, Sweden. Piles F and G showed high concentrations of PAHs among all the piles, as was the case of metals. CV was more than $80 \%$ for all PAHs, illustrating high variability among the piles. 
Table 2 Pile snow characteristics: (i) Max, min, and mean concentrations for sets of single point data and (ii) concentration in two composite samples: TSS, LOI, $\mathrm{pH}$, conductivity, and density

\begin{tabular}{|c|c|c|c|c|c|c|c|c|c|c|}
\hline Pile name & & Pile $A^{a}$ & Pile $\mathrm{B}^{\mathrm{a}}$ & Pile $C^{\mathrm{a}}$ & Pile D & Pile E & Pile F & Pile G & Pile H & Pile I \\
\hline \multirow{2}{*}{\multicolumn{2}{|c|}{$\begin{array}{l}\text { No. of samples } \\
\text { Sampling date }\end{array}$}} & 9 & 11 & 17 & 38 & 24 & 14 & 21 & 15 & 28 \\
\hline & & \multicolumn{3}{|c|}{11 Nov 2016} & \multicolumn{2}{|c|}{17 Jan 2018} & \multicolumn{2}{|c|}{27 Feb 2018} & \multicolumn{2}{|c|}{28 Feb 2018} \\
\hline \multirow[t]{6}{*}{ TSS (mg/l) } & $\begin{array}{l}\operatorname{Max} \\
\quad(\mathrm{mg} / \mathrm{l})\end{array}$ & 130 & 790 & 870 & 1200 & 1100 & 3300 & 3500 & 1100 & 870 \\
\hline & Min & 4.7 & 39 & 62 & 170 & 270 & 570 & 1200 & 38 & 45 \\
\hline & Mean \pm SD & $88 \pm 40$ & $290 \pm 220$ & $260 \pm 220$ & $420 \pm 220$ & $570 \pm 210$ & $\begin{array}{c}1600 \pm \\
770\end{array}$ & $\begin{array}{r}2100 \pm \\
530\end{array}$ & $300 \pm 320$ & $300 \pm 230$ \\
\hline & $\mathrm{CV}(\%)$ & 45 & 74 & 84 & 52 & 37 & 47 & 26 & 109 & 77 \\
\hline & $\mathrm{C}_{\mathrm{Comp1}}^{\mathrm{b}}$ & 93 & 300 & 240 & 1000 & 480 & 1900 & 2700 & 340 & 350 \\
\hline & $\mathrm{C}_{\mathrm{Comp} 2}{ }^{\mathrm{c}}$ & 130 & 340 & 180 & 370 & 640 & 1600 & 1700 & - & 310 \\
\hline \multirow[t]{6}{*}{ LOI (mg/l) } & Max & 41 & 110 & 120 & 75 & 98 & 340 & 320 & 74 & 99 \\
\hline & Min & 5.6 & 18 & 20 & 10 & 23 & 52 & 110 & 1.2 & 6 \\
\hline & Mean \pm SD & $31 \pm 11$ & $56 \pm 26$ & $55 \pm 24$ & $37 \pm 18$ & $52 \pm 20$ & $170 \pm 84$ & $190 \pm 52$ & $22 \pm 23$ & $38 \pm 25$ \\
\hline & $\mathrm{CV}(\%)$ & 35 & 46 & 44 & 49 & 38 & 50 & 27 & 105 & 66 \\
\hline & $\mathrm{C}_{\mathrm{Comp} 1}$ & 35 & 57 & 49 & 67 & 48 & 220 & 250 & 23 & 41 \\
\hline & $\mathrm{C}_{\text {Comp2 }}$ & 43 & 61 & 45 & 36 & 61 & 210 & 170 & - & 42 \\
\hline \multirow[t]{6}{*}{$\mathrm{pH}$} & Max & 6.6 & 6.9 & 6.8 & 7.9 & 7.8 & 7.8 & 7.3 & 6.9 & 7.7 \\
\hline & Min & 6.1 & 6.4 & 6.3 & 6.6 & 6.6 & 6.9 & 6.7 & 6.0 & 5.6 \\
\hline & Mean \pm SD & $6.4 \pm 0.1$ & $6.6 \pm 0.2$ & $6.5 \pm 0.1$ & $6.9 \pm 0.3$ & $7.1 \pm 0.3$ & $7.3 \pm 0.3$ & $7 \pm 0.2$ & $6.5 \pm 0.3$ & $6.7 \pm 0.4$ \\
\hline & $\mathrm{CV}(\%)$ & 2 & 3 & 2 & 4 & 4 & 4 & 3 & 5 & 6 \\
\hline & $\mathrm{C}_{\text {Comp1 }}$ & 6.2 & 6.4 & 6.4 & 7.1 & 7.1 & 7.3 & 7.3 & 6.6 & 7.0 \\
\hline & $\mathrm{C}_{\mathrm{Comp} 2}$ & 6.4 & 6.7 & 6.4 & 7 & 7.2 & 7.5 & 7.4 & - & 6.9 \\
\hline \multirow{6}{*}{$\begin{array}{l}\text { Conductivity } \\
(\mathrm{mS} / \mathrm{cm})\end{array}$} & Max & 6.8 & 0.48 & 3.6 & 1.98 & 1.19 & 11.76 & 23.30 & 8.93 & 2.87 \\
\hline & Min & 0.52 & 0.065 & 0.24 & 0.49 & 0.35 & 4.53 & 6.47 & 0.35 & 0.33 \\
\hline & Mean \pm SD & $2.1 \pm 2$ & $\begin{array}{r}0.19 \pm \\
0.15\end{array}$ & $\begin{array}{r}1.03 \pm \\
0.83\end{array}$ & $\begin{array}{r}1.14 \pm \\
0.35\end{array}$ & $\begin{array}{r}0.82 \pm \\
0.23\end{array}$ & $7.5 \pm 2$ & $17 \pm 3.6$ & $2 \pm 2.3$ & $1.4 \pm 0.74$ \\
\hline & $\mathrm{CV}(\%)$ & 95 & 79 & 81 & 31 & 28 & 26 & 22 & 113 & 54 \\
\hline & $\mathrm{C}_{\mathrm{Comp} 1}$ & 2.9 & 0.08 & 0.92 & 1.1 & 0.8 & 7.59 & 15.36 & 2.0 & 1.4 \\
\hline & $\mathrm{C}_{\text {Comp2 }}$ & 2.4 & 0.26 & 1.01 & 1.2 & 0.9 & 7.16 & 17.96 & - & 1.5 \\
\hline \multirow[t]{4}{*}{ Density $\left(\mathrm{kg} / \mathrm{m}^{3}\right)$} & Max & 297 & 221 & 249 & 391 & 427 & 356 & 515 & 242 & 245 \\
\hline & Min & 101 & 109 & 103 & 251 & 282 & 107 & 98.5 & 69.8 & 77.1 \\
\hline & Mean \pm SD & $\begin{array}{r}146 \pm \\
60.4\end{array}$ & $166 \pm 35.3$ & $157 \pm 43.8$ & $327 \pm 38.3$ & $335 \pm 39.2$ & $263 \pm 70.9$ & $350 \pm 85.5$ & $\begin{array}{r}131 \pm \\
45.2\end{array}$ & $\begin{array}{r}149 \pm \\
40.3\end{array}$ \\
\hline & $\mathrm{CV}(\%)$ & 41 & 21 & 28 & 12 & 12 & 27 & 24 & 34 & 27 \\
\hline
\end{tabular}

${ }^{a}$ Only the top 1-m layer of the pile was sampled

${ }^{\mathrm{b}}$ First of the two laterally composed samples

${ }^{\mathrm{c}}$ Second of the two laterally composed samples

3.2 Mass Load Estimations for Various Numbers of Samples and Their Combinations

The objective of snow storage pile sampling before disposal into a water body is to estimate the total pollutant loads in snow and, thereby, evaluate their potential impacts on the receiving water body. Best accuracy of such estimates is obtained for high density (i.e., the number of samples per area) of snow samples, but this sampling option is also the costliest and time consuming. Therefore, the analysis of load estimate accuracy was conducted by producing the best mass load estimates (BEMLs) using all the samples collected $n$ (i.e., all vertically composited samples in a 1-m rectangular 
Table 3 Maximum, minimum, and mean concentrations of metals in different snow piles

\begin{tabular}{|c|c|c|c|c|c|c|c|c|c|c|}
\hline Parameter & & Pile $A^{a}$ & Pile $\mathrm{B}^{\mathrm{a}}$ & Pile $C^{\mathrm{a}}$ & Pile $D^{b}$ & Pile $E^{b}$ & Pile $F^{b}$ & Pile $G^{b}$ & Pile $\mathrm{H}^{\mathrm{b}}$ & Pile I ${ }^{\mathrm{b}}$ \\
\hline \multirow[t]{6}{*}{$\mathrm{Zn}(\mu \mathrm{g} / \mathrm{l})$} & Max & & & & 390 & 520 & 1300 & 1300 & 180 & 340 \\
\hline & Min & & & & 62 & 140 & 230 & 280 & 15 & 29 \\
\hline & Mean \pm SD & & & & $150 \pm 68$ & $250 \pm 97$ & $740 \pm 280$ & $610 \pm 220$ & $67 \pm 58$ & $130 \pm 88$ \\
\hline & CV (\%) & & & & 45 & 38 & 37 & 36 & 87 & 68 \\
\hline & $\mathrm{C}_{\mathrm{Comp} 1}$ & 76 & 160 & 250 & 220 & 220 & 700 & 710 & 85 & 150 \\
\hline & $\mathrm{C}_{\mathrm{Comp} 2}$ & 83 & 190 & 190 & 660 & 300 & 660 & 460 & - & 160 \\
\hline \multirow[t]{6}{*}{$\mathrm{Cu}(\mu \mathrm{g} / \mathrm{l})$} & $\operatorname{Max}$ & & & & 59 & 98 & 240 & 200 & 68 & 220 \\
\hline & Min & & & & 7.6 & 14 & 47 & 49 & 14 & 22 \\
\hline & Mean \pm SD & & & & $27 \pm 11$ & $44 \pm 23$ & $140 \pm 62$ & $100 \pm 34$ & $30 \pm 16$ & $63 \pm 40$ \\
\hline & CV $(\%)$ & & & & 40 & 53 & 45 & 33 & 54 & 64 \\
\hline & $\mathrm{C}_{\text {Comp1 }}$ & 14 & 21 & 26 & 25 & 35 & 130 & 110 & 37 & 51 \\
\hline & $\mathrm{C}_{\text {Comp2 }}$ & 12 & 32 & 28 & 29 & 50 & 160 & 84 & - & 86 \\
\hline \multirow[t]{6}{*}{$\mathrm{Cd}(\mu \mathrm{g} / \mathrm{l})$} & $\operatorname{Max}$ & & & & 0.34 & 0.2 & 1.1 & 0.49 & 0.17 & 0.13 \\
\hline & Min & & & & 0.052 & 0.06 & 0.17 & 0.13 & 0.03 & 0.03 \\
\hline & Mean \pm SD & & & & $0.12 \pm 0.07$ & $0.12 \pm 0.04$ & $0.31 \pm 0.24$ & $0.28 \pm 0.08$ & $0.05 \pm 0.04$ & $0.06 \pm 0.04$ \\
\hline & CV (\%) & & & & 58 & 32 & 77 & 29 & 80 & 67 \\
\hline & $\mathrm{C}_{\mathrm{Comp} 1}$ & 0.1 & 0.05 & 0.14 & 0.14 & 0.1 & 0.48 & 0.25 & $<0.05$ & 0.06 \\
\hline & $\mathrm{C}_{\mathrm{Comp} 2}$ & 0.08 & 0.08 & 0.07 & 0.13 & 0.15 & 0.25 & 0.26 & - & 0.058 \\
\hline \multirow[t]{6}{*}{$\mathrm{Cr}(\mu \mathrm{g} / \mathrm{l})$} & Max & & & & 36 & 52 & 140 & 210 & 34 & 35 \\
\hline & Min & & & & 4.9 & 11 & 27 & 51 & 1.6 & 2.3 \\
\hline & Mean \pm SD & & & & $15 \pm 6.5$ & $26 \pm 9.2$ & $76 \pm 34$ & $96 \pm 36$ & $12 \pm 12$ & $16 \pm 10$ \\
\hline & CV (\%) & & & & 42 & 35 & 45 & 37 & 100 & 64 \\
\hline & $\mathrm{C}_{\text {Comp1 }}$ & 6 & 19 & 20 & 16 & 22 & 81 & 120 & 15 & 18 \\
\hline & $\mathrm{C}_{\text {Comp2 }}$ & 6.4 & 24 & 15 & 15 & 34 & 77 & 45 & - & 19 \\
\hline \multirow[t]{6}{*}{$\mathrm{Pb}(\mu \mathrm{g} / \mathrm{l})$} & Max & & & & 54 & 28 & 74 & 140 & 19 & 24 \\
\hline & Min & & & & 6.6 & 8.3 & 16 & 31 & 1.1 & 1.2 \\
\hline & Mean \pm SD & & & & $17 \pm 8.6$ & $17 \pm 5.1$ & $38 \pm 18$ & $59 \pm 21$ & $6.8 \pm 6.3$ & $7.5 \pm 5.7$ \\
\hline & CV (\%) & & & & 52 & 30 & 46 & 35 & 92 & 76 \\
\hline & $\mathrm{C}_{\mathrm{Comp1}}$ & 5.25 & 9.2 & 13.9 & 19 & 14 & 44 & 71 & 7.9 & 7.3 \\
\hline & $\mathrm{C}_{\mathrm{Comp} 2}$ & 5.84 & 12.2 & 8.62 & 16 & 20 & 38 & 51 & & 7.5 \\
\hline \multirow[t]{6}{*}{$\mathrm{V}(\mu \mathrm{g} / \mathrm{l})$} & Max & & & & 58 & 70 & 310 & 350 & 51 & 51 \\
\hline & Min & & & & 7.7 & 20 & 43 & 82 & 2.1 & 2.6 \\
\hline & Mean \pm SD & & & & $25 \pm 11$ & $41 \pm 13$ & $140 \pm 80$ & $160 \pm 63$ & $15 \pm 17$ & $20 \pm 15$ \\
\hline & $\mathrm{CV}(\%)$ & & & & 43 & 31 & 58 & 40 & 110 & 73 \\
\hline & $\mathrm{C}_{\mathrm{Comp} 1}$ & 6.4 & 20 & 26 & 31 & 34 & 130 & 160 & 18 & 21 \\
\hline & $\mathrm{C}_{\text {Comp2 }}$ & 7.5 & 25 & 16 & 25 & 47 & 110 & 58 & - & 23 \\
\hline
\end{tabular}

${ }^{a}$ Piles were sampled only in the top 1-m layer and metals were analyzed only in two composite samples from these piles, ${ }^{\mathrm{b}}$ Piles were sampled from the full depth and metals were analyzed in all single point samples from each pile and two composite samples Comp1 and Comp2, each of which combined one-half of volume-proportional subsamples from the respective halves and piles

grid), then calculating the load estimates for randomly selected smaller subsets of " $r$ " samples $(1 \leq r \leq(n-1))$, and assessing the deviations of load estimates from BEML. Two other estimates were defined: (a) CEML, the closest estimate of mass load to BEML, for a given number of random subsamples, Nss, and (b) FEML, the worst estimate of mass load compared to BEML, for a given number of random subsamples, Nss. All the load 
Table 4 PAH concentrations in the composite samples

\begin{tabular}{|c|c|c|c|c|c|c|c|c|c|}
\hline \multirow{3}{*}{$\begin{array}{l}\text { Pile } \\
\\
\text { Pile A }\end{array}$} & & \multicolumn{2}{|c|}{$\begin{array}{l}\text { PAH with } \\
\text { highest } \\
\text { concentrations }\end{array}$} & \multirow{2}{*}{$\begin{array}{l}\text { Ant } \\
(\mu \mathrm{g} / \mathrm{l})\end{array}$} & \multirow{2}{*}{$\begin{array}{l}\text { Sum of } 16 \text { PAHs } \\
(\mu \mathrm{g} / \mathrm{l})\end{array}$} & \multirow{2}{*}{$\begin{array}{l}\text { Sum carcinogenic } \\
(\mu \mathrm{g} / \mathrm{l})\end{array}$} & \multirow{2}{*}{$\begin{array}{l}\begin{array}{l}\text { Sum LMW } \\
(\mu \mathrm{g} / \mathrm{l})\end{array} \\
0.067\end{array}$} & \multirow{2}{*}{$\begin{array}{l}\begin{array}{l}\text { Sum MMW } \\
(\mu \mathrm{g} / \mathrm{l})\end{array} \\
0.19\end{array}$} & \multirow{2}{*}{$\begin{array}{l}\text { Sum HMW } \\
(\mu \mathrm{g} / \mathrm{l})\end{array}$} \\
\hline & $\mathrm{A} 1^{\mathrm{a}}$ & Flt & 0.064 & & & & & & \\
\hline & $\mathrm{A} 2^{\mathrm{a}}$ & Flt & 0.064 & BRL & 0.37 & 0.13 & 0.05 & 0.16 & 0.15 \\
\hline \multirow[t]{2}{*}{ Pile B } & $\mathrm{B} 1^{\mathrm{a}}$ & Pyr & 0.028 & BRL & 0.15 & 0.035 & 0.025 & 0.085 & 0.04 \\
\hline & $\mathrm{B} 2^{\mathrm{a}}$ & Pyr & 0.11 & BRL & 0.59 & 0.26 & 0.025 & 0.26 & 0.31 \\
\hline \multirow[t]{2}{*}{ Pile C } & $\mathrm{C} 1^{\mathrm{a}}$ & Flt & 0.28 & 0.02 & 1.5 & 0.68 & 0.05 & 0.71 & 0.79 \\
\hline & $\mathrm{C} 2^{\mathrm{a}}$ & Pyr & 0.11 & BRL & 0.54 & 0.19 & 0.038 & 0.26 & 0.24 \\
\hline \multirow[t]{2}{*}{ Pile D } & D1 & Flt & 0.4 & 0.013 & 2 & 0.88 & 0.02 & 0.94 & 1 \\
\hline & D2 & Flt & 0.21 & BRL & 1.2 & 0.57 & 0.02 & 0.49 & 0.67 \\
\hline \multirow[t]{2}{*}{ Pile E } & E1 & Pyr & 0.19 & 0.011 & 1 & 0.39 & 0.01 & 0.51 & 0.46 \\
\hline & E2 & Pyr & 0.57 & 0.033 & 3.3 & 1.4 & 0.09 & 1.5 & 1.7 \\
\hline \multirow[t]{2}{*}{ Pile F } & $\mathrm{F} 1$ & Pyr & 1.2 & 0.054 & 5.1 & 1.6 & 0.15 & 2.9 & 2 \\
\hline & $\mathrm{F} 2$ & Pyr & 0.73 & 0.023 & 3 & 0.92 & 0.16 & 1.7 & 1.2 \\
\hline \multirow[t]{2}{*}{ Pile G } & G1 & Pyr & 0.38 & 0.017 & 2.2 & 0.82 & 0.06 & 1 & 1.1 \\
\hline & G2 & Pyr & 0.58 & 0.024 & 3.5 & 1.3 & 0.09 & 1.6 & 1.8 \\
\hline Pile H & H1 & Flt & 0.12 & BRL & 0.5 & 0.18 & 0.02 & 0.28 & 0.22 \\
\hline \multirow[t]{2}{*}{ Pile I } & I1 & Pyr & 0.14 & BRL & 0.7 & 0.23 & 0.02 & 0.35 & 0.3 \\
\hline & $\mathrm{I} 2$ & Pyr & 0.18 & BRL & 0.9 & 0.33 & 0.02 & 0.45 & 0.42 \\
\hline Mean \pm SD & & & & & $1.3 \pm 1.4$ & $0.5 \pm 0.5$ & $0 \pm 0$ & $0.7 \pm 0.7$ & $0.6 \pm 0.6$ \\
\hline CV $(\%)$ & & & & & 100 & 97 & 84 & 107 & 99 \\
\hline
\end{tabular}

${ }^{\text {a }}$ Piles were sampled only in the top layer

${ }^{\mathrm{b}} B R L$ below reporting limit (reporting limit for Ant is $0.01 \mu \mathrm{g} / \mathrm{l}$ )

estimates were produced by means of the algorithm described in the "Materials and Methods" section.

Table 5 shows the estimated mass loads of TSS and six metals produced by considering all the samples (i.e., the BEML). For all piles, except pile D, the magnitudes of mass loads of total metals followed this descending order: $\mathrm{Zn}>\mathrm{Cu} \approx \mathrm{V}>\mathrm{Cr}>\mathrm{Pb}>\mathrm{Cd}$. For pile $\mathrm{D}, \mathrm{Pb}$ had a higher mass load compared to $\mathrm{Cr}$. For all the metals, the highest mass load was in pile $\mathrm{G}$ and the lowest was in pile $\mathrm{H}$.

As an example, Fig. 4 shows the percentage deviation of the calculated CEML and FEML deviations from Zn BEML, for pile E, and all possible sample subset combinations. The average values of percentage deviation of the calculated mass load from BEML, for various sample combinations, are also displayed in Fig. 4. This figure represents expected average variations in the estimated pollutant loads calculated for various numbers of random vertically composed samples. When collecting a set of five random grid samples, the average variation in estimated loads is about $20 \%$, with FEML value of about $75 \%$. The percentage deviation of CEML of total metals from the BEML was below $15 \%$ for all possible combinations (for total $\mathrm{Zn}$ in pile $\mathrm{E}$, the value is below 1\%, Fig. 4). It implies that there will be one or more combinations of samples, which will produce mass load estimates as close as $15 \%$ to BEML with various sampling efforts. The percentage deviation of FEML from BEML decreases rapidly as the number of samples in subsets increases. Thus, as the number of samples increases, the accuracy in estimating mass load increases. The total number of snow samples collected is important since the collection and processing of samples requires significant resources, including time and labor. The total cost for collecting and analyzing first sample was estimated at 950 USD (approximately $850 €$ ), which included labor (retrieved from Eurostat data for labor cost data in Sweden), transportation, sampling equipment, sample preparation, and the cost of analyses. For each additional sample, the cost per sample dropped to about 400 USD (approximately $350 €$ ), which includes only labor and analytical costs. 
Table 5 The best estimates (BEML) of TSS and total and dissolved metal loads ( $\mathrm{Zn}, \mathrm{Cu}, \mathrm{Cd}, \mathrm{Pb}, \mathrm{Cr}$, and V) for snow piles D, E, F, G, H, and I, obtained by considering all the available vertically composed samples

\begin{tabular}{|c|c|c|c|c|c|c|}
\hline Parameter & Pile D & Pile E & Pile F & Pile G & Pile H & Pile I \\
\hline Water volume $\left(\mathrm{m}^{3}\right)^{\mathrm{a}}$ & 12.7 & 10.9 & 3.6 & 7.9 & 1.8 & 4.3 \\
\hline No. of samples & 38 & 24 & 14 & 21 & 15 & 28 \\
\hline TSS (mg) & 5400 & 6700 & 6300 & 18,000 & 480 & 1400 \\
\hline Total Zn (mg) & 1900 & 3000 & 2800 & 5500 & 120 & 620 \\
\hline Dissolved Zn (mg) & 210 & 260 & 46 & 67 & 26 & 120 \\
\hline Total Cu (mg) & 360 & 520 & 560 & 910 & 52 & 330 \\
\hline Dissolved Cu (mg) & 49 & 41 & 29 & 34 & 19 & 60 \\
\hline Total Cd (mg) & 1.5 & 1.4 & 1.1 & 2.5 & 0.1 & 0.3 \\
\hline Dissolved Cd (mg) & 0.5 & 0.3 & 0.2 & 0.6 & 0.1 & 0.1 \\
\hline Total Cr (mg) & 200 & 310 & 300 & 850 & 20 & 78 \\
\hline Dissolved Cr (mg) & 0.7 & 1.3 & 0.4 & 1 & 0.1 & 0.2 \\
\hline Total Pb (mg) & 220 & 200 & 150 & 530 & 12 & 35 \\
\hline Dissolved $\mathrm{Pb}$ (mg) & 0.6 & 0.3 & 0.1 & 0.3 & 0.2 & 0.1 \\
\hline Total V (mg) & 330 & 480 & 550 & 1300 & 25 & 98 \\
\hline Dissolved V (mg) & 2.3 & 2.1 & 2.3 & 1.6 & 0.3 & 0.9 \\
\hline
\end{tabular}

${ }^{a}$ Volume of water stored in the snow pile was calculated by multiplying SWE and the area of pile footprint

BEML, FEML, and the ratio of FEML to BEML of TSS and six metals in piles D to I are shown in Table 6. The detailed results for these piles are attached in the online resource (Figs. 1, 2, 3, 4, 5, and 6). It is clear from Table 6 that the same sample yielded FEML for all presented parameters, which indicates the correlation between TSS and metals in snow samples. The FEML to BEML ratio varied from 1.6 (for pile I, TSS) to 5 (for pile G, V) and indicated the errors associated with estimation of pollutant loads from single snow column samples.

For the collected sets of snow samples, the probability of choosing subsets of samples, which can yield an ML closest to BEML or furthest from BEML, depends on the possible number of combination $\left(\mathrm{C}_{(\mathrm{n}, \mathrm{r})}\right)$. The total possible combinations can be calculated using Eq. 8.

$C_{(n, r)}=\frac{n !}{(r !(n-r) !)}$

$C_{(\mathrm{n}, \mathrm{r})} \quad$ Number of combinations

$n \quad$ Total number of samples in a snow pile

$r \quad$ Number of samples chosen for calculation of the mass load
In actual field studies, one would choose the number of samples $r$ to be collected. The snow quality variation data presented here are valid just for the experimental data set discussed, but provide indications of variability in piled snow quality.

One advantage of systematic grid sampling is the ability to characterize snow quality in space, within the pile footprint area. To assess the significance of spatial variation of snow quality in the $\mathrm{x}-\mathrm{y}$ plane, mass load estimates for single point snow column samples were compared to those obtained for multiple column sample, which was composed. It can be observed in Fig. 4 that a single point snow column sample deviates from the BEML estimate in the range from 0.84 to $140 \%$, which indicates high dispersion of data in the x-y space. Further information on such variation can be obtained by plotting average percentage deviations of all possible sample combinations from BEML in Fig.4. For total Zn mass load in pile $\mathrm{E}$, the percentage deviations of mass load estimated from composite samples from BEML were $27 \%$ and $22 \%$. At the same time, to produce a mass load of total $\mathrm{Zn}$ as close as $25 \%$ to BEML, around 17 samples were needed. Thus, composite sampling allows estimating the mass loads with a better precision than single snow column sampling.

As an example, the box and whisker plot in Fig. 5 shows the percentage deviation of the calculated $\mathrm{Zn}$ 
Fig. 4 Percentage deviation of the closest and furthest mass load estimates from BEML and average percentage deviations of $\mathrm{Zn}$ in pile $\mathrm{E}$

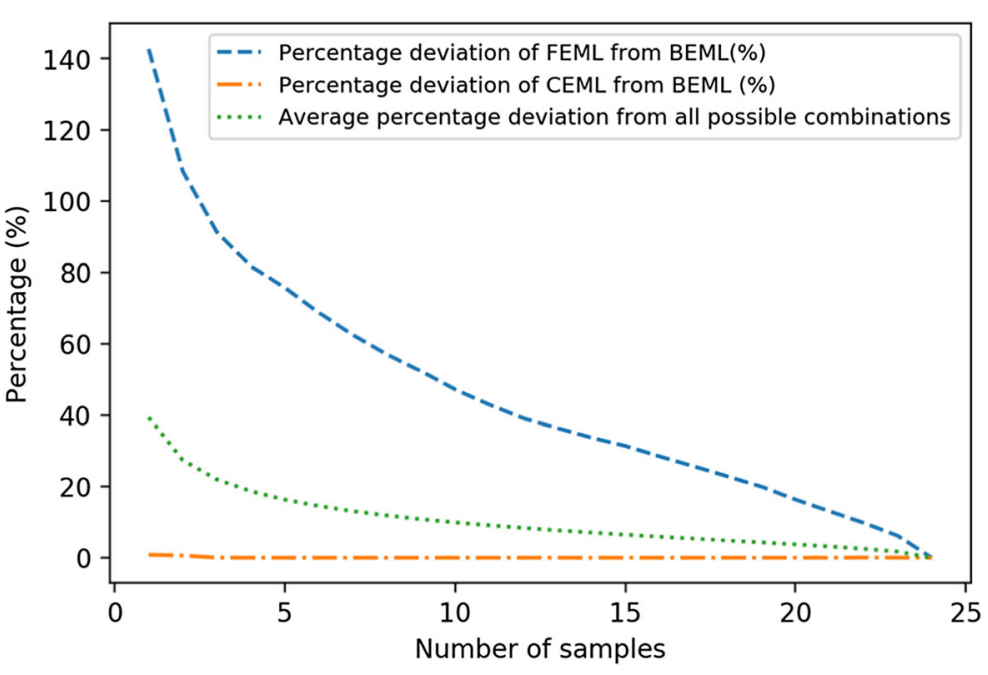

mass loads in pile E from BEML, when basing such calculations on various numbers of point samples (varying from 1 to $N$, where $N$ is the total number of samples) and considering all combinations of the selected subsets in the total set of $N$ samples. The whiskers in the plot extend from the smallest to the largest percentage deviations that are not outliers. The orange line in the box plot represents the median value of the percentage deviations, which divides the lower $50 \%$ of the percentage deviation values from the upper $50 \%$. The interquartile range (height of the box) indicates the variability in the percentage deviation values (McLeod 2019). As the number of samples increases, the interquartile range decreases, implying that the data is less dispersed and

Table 6 BEML, FEML (calculated by considering a single column sample), and FEML/BEML ratios of TSS and six metals (Zn, Cu Cd, $\mathrm{Cr}, \mathrm{Pb}$, and $\mathrm{V}$ ) for piles $\mathrm{D}$ to I

\begin{tabular}{|c|c|c|c|c|c|c|c|c|}
\hline Pile name & & TSS & $\mathrm{Zn}$ & $\mathrm{Cu}$ & $\mathrm{Cd}$ & $\mathrm{Cr}$ & $\mathrm{Pb}$ & V \\
\hline \multirow[t]{3}{*}{ Pile D } & BEML $(\mu g)$ & 5356 & 1943 & 354.9 & 1.49 & 201.6 & 221 & 326.7 \\
\hline & FEML $(\mu g)$ & $20,889(\mathrm{D} 7)^{\mathrm{a}}$ & 6858.5 (D7) & 856.4 (D7) & 5.9 (D7) & 630.1 (D7) & 936.5 (D7) & 1006.1 (D7) \\
\hline & FEML/BEML & 3.9 & 3.5 & 2.4 & 4.0 & 3.1 & 4.2 & 3.1 \\
\hline \multirow[t]{3}{*}{ Pile E } & BEML ( $\mu \mathrm{g})$ & 6692.9 & 2969 & 519 & 1.4 & 310 & 196 & 482 \\
\hline & FEML $(\mu \mathrm{g})$ & $15,393.1(\mathrm{E} 20)$ & 7207 (E20) & 1371 (E20) & 2.7 (E20) & 721 (E20) & 389 (E20) & 985 (E20) \\
\hline & FEML/BEML & 2.3 & 2.4 & 2.6 & 2.0 & 2.3 & 2.0 & 2.0 \\
\hline \multirow[t]{3}{*}{ Pile F } & BEML ( $\mu g)$ & 6313 & 2809 & 560 & 1.1 & 300 & 150 & 552 \\
\hline & FEML $(\mu \mathrm{g})$ & 23,390 (F7) & 8860 (F7) & 2032 (F8) & $3(\mathrm{~F} 7)$ & $1020(\mathrm{~F} 7)$ & $520(\mathrm{~F} 7)$ & 2169 (F7) \\
\hline & FEML/BEML & 3.7 & 3.2 & 3.6 & 2.8 & 3.5 & 3.5 & 3.9 \\
\hline \multirow[t]{3}{*}{ Pile G } & BEML $(\mu \mathrm{g})$ & $17,686.2$ & 5502 & 909 & 2.46 & 851 & 533 & 1347 \\
\hline & FEML $(\mu \mathrm{g})$ & $68,124.7$ (G11) & $26,082(\mathrm{G} 11)$ & 3893 (G11) & 9.5 (G11) & 4068 (G11) & $2628(\mathrm{G} 11)$ & 6793 (G11) \\
\hline & FEML/BEML & 3.9 & 4.7 & 4.3 & 3.9 & 4.8 & 4.9 & 5.0 \\
\hline \multirow[t]{3}{*}{ Pile H } & BEML ( $\mu g)$ & 481.5 & 114.6 & 51.5 & 0.08 & 20 & 12.15 & 25.3 \\
\hline & FEML $(\mu \mathrm{g})$ & $1215(\mathrm{H} 8)$ & $371.8(\mathrm{H} 8)$ & 150 (H8) & $0.4(\mathrm{H} 8)$ & $70.2(\mathrm{H} 8)$ & 39.6 (H8) & $80(\mathrm{H} 8)$ \\
\hline & FEML/BEML & 2.5 & 3.2 & 2.9 & 4.8 & 3.5 & 3.3 & 3.2 \\
\hline \multirow[t]{3}{*}{ Pile I } & BEML $(\mu \mathrm{g})$ & 1387 & 620 & 327.3 & 0.28 & 78.4 & 35.2 & 98.1 \\
\hline & FEML $(\mu \mathrm{g})$ & 5063.7 (I9) & 2053.6 (I9) & 1585 (I10) & 0.87 (I9) & 241.9 (I9) & 121.9 (I9) & 360 (I9) \\
\hline & FEML/BEML & 1.6 & 3.3 & 4.8 & 3.2 & 3.1 & 3.5 & 3.7 \\
\hline
\end{tabular}

\footnotetext{
${ }^{\text {a }}$ Sample code in the bracket indicates the sample which yielded FEML, when single snow column samples were considered to estimate the pile pollutant loads
} 
Fig. 5 Box and whisker plot of the percentage deviation of the calculated $\mathrm{Zn}$ mass loads in pile $\mathrm{E}$ from BEML, based on various numbers of point samples and all their combinations selected from the whole set of 20 samples

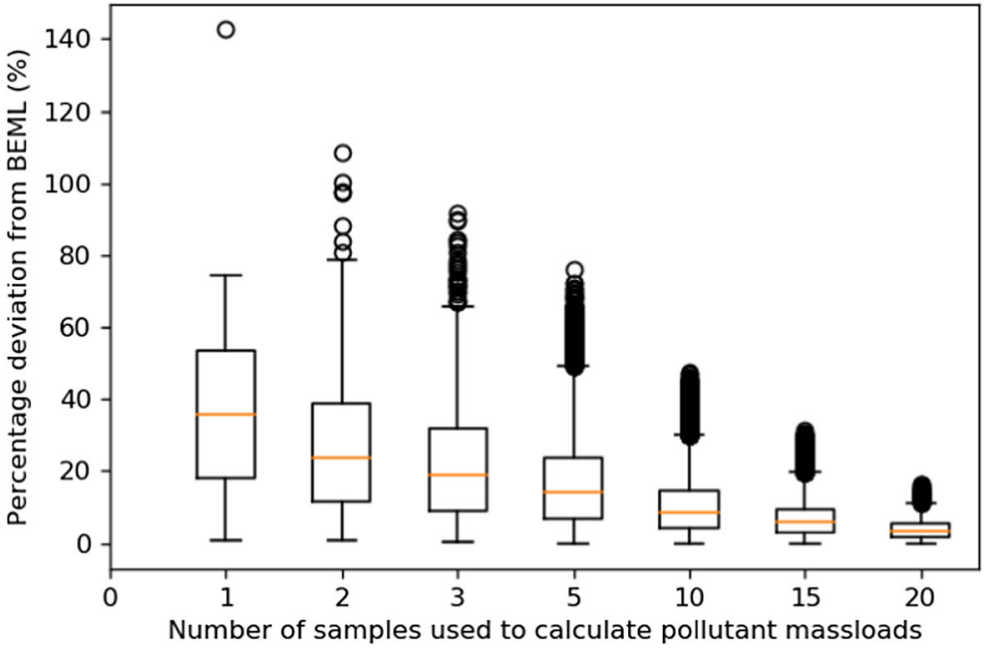

The deviation of mass loads of total metals, calculated at individual sampling points from BEML values, was used to produce a heat map facilitating visualization of the data. The heat maps indicating the positions of sampling points are shown in Fig. 6. In the heat map, the squares represent the sampling points and the square color indicates the deviation of the mass load calculated the calculated mass loads are closer to BEML. The overall spread (marked by the extreme values at the end of whiskers) also decreases with the increasing number of samples, indicating the same tendency. The analogous data for all the other studied metals $(\mathrm{Cd}, \mathrm{Cr}$, $\mathrm{Cu}, \mathrm{Pb}$, and $\mathrm{V}$ ) and piles (piles F, G, H, and I) are shown in the online resource (online resource Figs. 7-12).

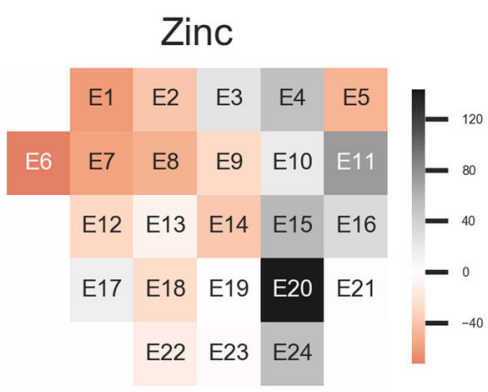

Copper

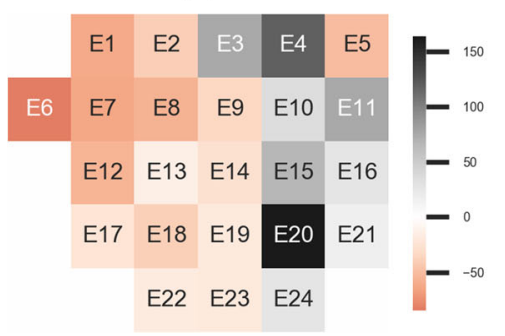

Fig. 6 Heat map showing percentage deviation of mass loads, calculated from single samples, from BEML at each sampling location (grid square) for total $\mathrm{Zn}, \mathrm{Cd}, \mathrm{Cr}, \mathrm{Cu}, \mathrm{Pb}$, and $\mathrm{V}$ in pile
Cadmium

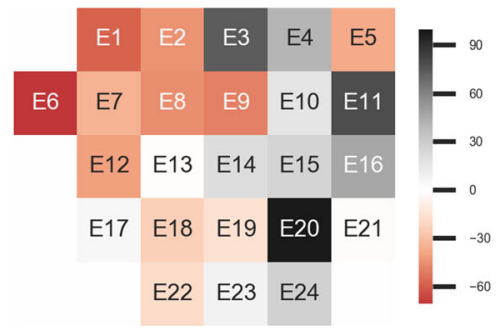

Lead

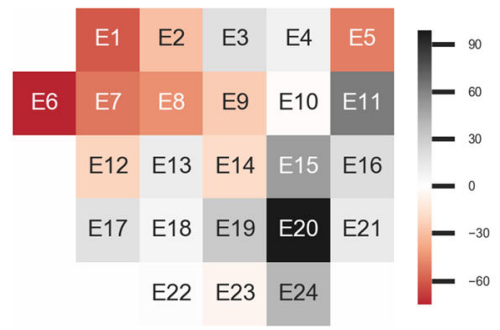

Chromium

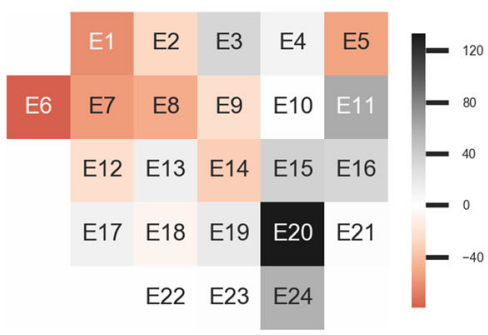

\section{Vanadium}

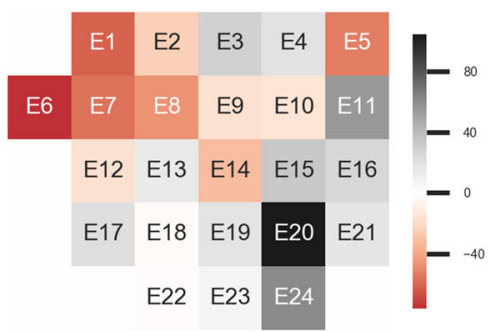

E. Light gray color represents the highest deviation and black represents the lowest deviation 
for the corresponding sampling point from BEML. The deviation is positive if the mass load at the sampling point exceeds BEML. For positive deviations, the square color varies from white to black, with white representing the smallest deviation and black indicating the greatest deviation. If the calculated mass load at a point was smaller than BEML, the deviation is marked as negative and its color varies from white to red. White represents the smallest negative deviation and red represents the greatest negative deviation. Heat maps for all other piles are shown in the online resource (online resource 13-17). In pile E, sample E20 produced the mass load furthest from BEML for all the studied metals; in pile D, it was sample D7, in pile F sample F7 (F8 for $\mathrm{Cu}$ ), in pile $\mathrm{G}$ sample $\mathrm{G} 11$, in pile $\mathrm{H}$ sample $\mathrm{H} 8$, and in pile I sample I 9, respectively. The sample, which produces the mass load furthest from BEML, was the same for various metals.

The total numbers of samples required to estimate the mass load with about 50\% deviation from BEML $\left(N_{50}\right)$ for piles E, F, G, H, and I are displayed in Table 7. This number varies for individual piles and with sample location (about 9 (pile E) to 17 (pile I), or 40 to $60 \%$ of the total number of samples collected in the corresponding piles). $N_{50}$ depends on the pile snow homogeneity, rather than just size. Note that pile I was the largest and had the snow quality $\mathrm{CV}$ about $70 \%$; pile $\mathrm{E}$ was the second largest. The samples needed to produce a mass load estimate within 50\% of BEML increase with the size of the pile. Pile I was the largest pile (presented in Table 7), and for that pile, about 17 samples were requited to produce a mass load estimate within $50 \%$ of BEML. Pile E is the second largest pile presented in Table 7, which required only around 9 samples to produce a mass load estimate within 50\% of BEML. From Table 3, it is clear that, for metals, pile $\mathrm{E}$ has low $\mathrm{CV}$ values (CV around 35\%) compared to pile I (CV around $70 \%$ ), indicating relative homogeneity of pile E. Even though the pile is large, the quality of stored snow is relatively homogeneous, and fewer samples are required produce a mass load estimate within $50 \%$ of BEML.

3.3 Weighing the Environmental Significance of Snow Quality Parameters

The event mean concentration (EMC), which is defined as the event mass load of a pollutant divided by the event runoff volume, is commonly used to characterize stormwater quality (USEPA 1983). A similar concept was adopted here for processing snow and snowmelt quality data by defining the snow pile mean concentration, SPMC, as the pollutant mass load in the snow pile snowmelt divided by the volume of water in the pile (see Eq. 5). Results of such calculations are shown in Table 8 for piles D-I and the five metals for which guideline values were available. The calculated SPMCs were compared to the stormwater effluent guidelines developed by the Gothenburg Municipality (2013) for discharges of polluted stormwater into the receiving waters. It can be inferred from Table 8 that with respect to potential exceedance of the guideline stormwater

Table 7 The estimated number of samples needed to produce a load estimate within $\pm 50 \%$ of BEML of various metals in piles E, F, G, H and I

\begin{tabular}{|c|c|c|c|c|c|}
\hline Pile name & Pile E & Pile F & Pile G & Pile H & Pile I \\
\hline Total samples & 24 & 14 & 21 & 15 & 28 \\
\hline Size of pile & $5 \times 5 \times 1.6$ & $4 \times 4 \times 1.6$ & $6 \times 4 \times 2.1$ & $5 \times 3 \times 1.5$ & $7 \times 4 \times 1.7$ \\
\hline Snow residence time (hours) & 20 & 28 & 28 & 12 & 12 \\
\hline Tot $\mathrm{Cd}$ & $8(52)^{\mathrm{a}}$ & $7(50)$ & $11(50)$ & $9(51)$ & $17(50)$ \\
\hline Tot $\mathrm{Cr}$ & $8(48)$ & $10(50)$ & $13(49)$ & $11(48)$ & $18(48)$ \\
\hline Tot $\mathrm{Cu}$ & $11(52)$ & $11(48)$ & $12(51)$ & $7(46)$ & $18(50)$ \\
\hline Tot $\mathrm{Pb}$ & $7(48)$ & $10(49)$ & $13(49)$ & $11(46)$ & $17(50)$ \\
\hline Tot V & $7(50)$ & $11(50)$ & $13(51)$ & $11(48)$ & $17(52)$ \\
\hline Tot $\mathrm{Zn}$ & $9(52)$ & $9(49)$ & $13(49)$ & $10(49)$ & $17(51)$ \\
\hline Average & 8 & 10 & 13 & 10 & 17 \\
\hline Average/Total (\%) & 35 & 69 & 60 & 66 & 62 \\
\hline
\end{tabular}

${ }^{\text {a }}$ Percentage deviation from BEML yielded by calculating mass load using the number of samples presented in the table 
Table 8 The snow pile mean concentrations (SPMC in $\mu \mathrm{g} / \mathrm{l}$ ) of $\mathrm{Cd}, \mathrm{Cu}, \mathrm{Ni}, \mathrm{Pb}$ and $\mathrm{Zn}$ in piles D-I. The SPMC values that exceed the guideline values are bolded

\begin{tabular}{llllll}
\hline Parameter & $\mathrm{Zn}$ & $\mathrm{Cu}$ & $\mathrm{Cd}$ & $\mathrm{Pb}$ & $\mathrm{Ni}$ \\
\hline Guidelines ${ }^{a}$ concentration $\mu \mathrm{g} / \mathrm{l}$ & 30 & 10 & 0.4 & 14 & 40 \\
SPMC & & & & & \\
Pile D & $\mathbf{4 9}$ & 8.9 & 0.04 & 5.6 & 1.5 \\
Pile E & $\mathbf{8 9}$ & $\mathbf{1 6}$ & 0.04 & 5.8 & 3.4 \\
Pile F & $\mathbf{1 8 0}$ & $\mathbf{3 4}$ & 0.07 & 9.4 & 6.7 \\
Pile G & $\mathbf{1 6 0}$ & $\mathbf{2 8}$ & 0.08 & $\mathbf{1 6}$ & 9.4 \\
Pile H & 8 & 4 & 0.01 & 0.85 & 0.56 \\
Pile I & 20 & 10 & 0.01 & 1.1 & 0.84 \\
Average SPMC & 84 & 17 & 0.042 & 6.5 & 3.7 \\
\hline
\end{tabular}

${ }^{a}$ Gothenburg Municipality (2013)

concentrations, $\mathrm{Zn}$ is the most critical parameter, followed by $\mathrm{Cu}$ and possibly $\mathrm{Pb}$. The guideline concentrations of $\mathrm{Zn}, \mathrm{Cu}$, and $\mathrm{Pb}$ were exceeded in four (piles $\mathrm{D}, \mathrm{E}, \mathrm{F}$, and G), three (piles E, F, and G), and one (pile G) piles, respectively. Hence, the interpretation of $\mathrm{Zn}$ data should receive the highest priority.

Port areas are characterized by numerous sources of air and water pollution (Gupta et al. 2005) impacting on the quality of surface runoff and ultimately the quality of receiving waters. A thorough literature search has not yielded any data on stormwater quality characteristics in port areas. However, the published discussion of pollution sources in port areas (Gupta et al. 2005) indicates that besides transportation, there are other pollution sources, including the air pollution from ship traffic and the handling of cargo. Thus, concentrations of pollutants in port land runoff are likely to exceed those corresponding to traffic only. Furthermore, the published data on quality of runoff from trafficked areas may differ from those in port areas, because of differences in traffic flows: in the latter case, traffic is largely stop-and-go. Since the study area consists mostly of road surfaces, traffic-related emissions are likely to be among the main sources of $\mathrm{Zn}$ and $\mathrm{Cu}$ (Gunawardena et al. 2015) in the study area. Studies on the correlation of metals in road runoff indicated that the metals with strongest correlations to traffic intensity were $\mathrm{Cu}, \mathrm{Sb}$, and $\mathrm{Zn}$, and the main sources of these metals were identified as brake lining and tire wear (Hjortenkrans et al. 2008). High presence of heavy trucks and frequent braking and stopping (Hjortenkrans et al. 2006) connected with operation of the container terminal in the
Frihamnen port area may contribute to elevated concentrations of $\mathrm{Zn}$ and $\mathrm{Cu}$ in snow cleared from the port area and the pollution of the receiving waters. After dumping snow into the receiving waters, snow melting and initial dilution take place in the mixing zone of the receiving water body, and coarse sediment is likely to settle out on the bottom. The effluent mixing depends on both the conditions in the water body and characteristics of the effluent (Jirka et al. 1996). Thus, evaluation of the fate of pollutants from dumped snow would require investigations of mixing in the receiving waters in Frihamnen.

\section{Discussion}

The snow disposal causes negative impacts on various elements of the environment, including soils, vegetation, surface waters, and groundwater, and ultimately on aquatic life (Corsi et al. 2010), depending on the ultimate fate of pollutants. Thus, the knowledge of mass loads and pathways of pollutants in snow is vital for developing sustainable snow disposal practices. The sampling and analysis of snow before disposal provides information on pollutant load discharged and their potential impacts on the environment.

TSS, LOI, conductivity, and total metal $(\mathrm{Zn}, \mathrm{Cu}, \mathrm{Cd}$, $\mathrm{Cr}, \mathrm{Pb}$, and $\mathrm{V}$ ) concentrations in piles $\mathrm{F}$ and $\mathrm{G}$ were the highest, since these piles had the highest SRT (snow residence time). The SRT, which equals the time of snow exposure to the pollutant influx (Viklander 1998), varied in our study from 12 to $28 \mathrm{~h}$. High Pearson correlation coefficient values $(>0.80)$ were noted between SRT and pollutant concentrations and indicated pollutant accumulation with increasing SRT. Positive correlations of SRT and pollutant accumulations were earlier reported by Viklander $(1998,1999)$ and Moghadas et al. (2015). The coefficient of variation, $\mathrm{CV}$, calculated for sampled concentrations within individual piles was introduced to standardize the results and compare the homogeneity of different piles sampled. According to Meyer et al. (2009), the ions in snow accumulate on the surface of snow grains, and when snow starts to melt, such ions are flushed out by the meltwater moving downward. This explains the high CV values in piles sampled on 11 November 2016, only in the top pile layer (piles A, B, and C), which caused high variance in the observed water quality parameters. These results also revealed the necessity of sampling the piles over their full depth. For calculation of pollutant 
loads in piles, the use of vertically composed snow samples eliminates the need to measure the variation of pollutant concentrations along the vertical.

The sum of concentrations of 16 USEPA PAHs varied from 0.15 (for pile B) to $5.1 \mu \mathrm{g} / 1$ (for pile F) in the studied snow piles. These concentrations are comparable to the PAH concentrations $(0.6 \mu \mathrm{g} / \mathrm{l}$ to $3.5 \mu \mathrm{g} / \mathrm{l})$ in snow samples collected from snowbanks along a road in Luleå with ADT of 9200 vehicles (Reinosdotter et al. 2006). The presence of PAHs in the aquatic environment is of great concern, because some of them are recognized as carcinogens: $\mathrm{Chr}$, Bbf, Bkf, $\mathrm{BaP}$, IndP, DahA, and BaA (Aziz et al. 2014). When the PAHs in snow enter the aquatic environment, they are mostly bound to the sediment (HongWei et al. 2014). Thus, the fate and impacts of PAHs in the receiving waters depend on the sediment water partitioning of specific PAH substances (Guo et al. 2009). The Annual Average Environmental Quality Standards (AA-EQS) for Ant and Flt in all types of surface waters are $0.1 \mu \mathrm{g} / 1$ (Directive 2008/105/EC 2008). While the concentrations of Ant were below this standard value in all the studied piles, the Flt concentrations in snow samples exceeded the AA-EQS value in piles C, D, E, F, G, H, and I. Here, the concentrations of PAHs in melted snow are compared to the environmental quality standards for surface water, because there are no quality standards available for PAHs in snow. Therefore, Flt concentrations in snow exceeding the AA-EQS for surface water do not imply that the polluted snow possesses risk to the receiving waters. The assessment of such a risk would require detailed considerations of melting and dispersion of snow in the receiving waters.

The total pollutant load in a snow pile is an important factor indicating the potential environmental impacts caused by dumping snow in open water bodies (Viklander 1998). Estimation of mass load from sampled concentrations is complex, since snow in piles can be heterogeneous. In this study, the best mass loads were estimated from systematic pile sampling and spatial analysis covering the whole snow pile. However, such sampling can be time consuming and expensive. The selection of sampling design depends on the project objectives. If one of the objectives is to identify the presence of "hot spots" (i.e., the areas with high pollutant concentrations), or to fully cover the sampling site, systematic grid sampling is the best sampling method (Malherbe 2002; USEPA 2002). Concerning the comparison of loads of individual metals, the data in Table 5 shows the descending ranking order $\mathrm{Zn}>\mathrm{Cu}>\mathrm{Cr}>\mathrm{Cd}$, which is identical to that presented in Moghadas et al. (2015) for roadside snowbanks. The highest metal mass loads were observed in pile $\mathrm{G}(\mathrm{SRT}=28 \mathrm{~h})$ and the lowest in pile I $(\mathrm{SRT}=12 \mathrm{~h})$. This relation confirms that the pollution loads in snow tend to increase with time (Viklander 1998). In pile E, the concentrations of total metals were lower than in pile $\mathrm{F}$ (Table 3 ), but the mass loads were higher in pile $\mathrm{E}$, which was larger than pile $\mathrm{F}$. Thus, assessing the impact of snow dumping just on the basis of pollutant concentrations is not recommended, without also considering the pile size.

The percentage deviation of the closest mass loads of total metals from BEML was below $15 \%$, indicating that there will be at least one sample combination, which will yield a mass load as close as $15 \%$ to the BEML. Figure 4 illustrates the dilemma in estimation of mass load from single snow column sampling. If a single sample was withdrawn from pile E, the calculated mass load could differ as much as $140 \%$ from BEML. These deviations were as high as $400 \%$ for pile $\mathrm{H}(\mathrm{Cd})$, pile I $(\mathrm{Cu}$ ), and pile $\mathrm{G}(\mathrm{Va})$ (online resource Figs. 1, 2, 3, 4, 5 , and 6). Thus, single snow column sampling suffers from high uncertainties and can significantly under- or overestimate the actual mass load of pollutants, and with rare exceptions, it cannot be representative sample for the whole pile (Brewer et al. 2017). As the number of samples used in the estimation of mass load increases, the deviation of calculated mass loads from BEML decreases.

The choice of the sampling technique depends on the site access, properties of snow, and analytical costs (Malherbe 2002). The composite samples composed from single snow column samples showed much less variability than discrete samples. The same was reported in the US EPA Guidelines on Choosing a Sampling Design for Environmental Data Collection (USEPA 2002). The deviations of the mass loads calculated from composite samples from BEMLs varied from 1.3 (for $\mathrm{Pb}$ in sample comp2 from pile D) to $59 \%$ (for $\mathrm{V}$ in sample comp2 from pile G). A full set of data is in online resource, Table 2. Compared to the systematic grid sampling, the composite sampling has an advantage of lower analytical costs, because fewer samples need to be analyzed. When sample composition is done directly by a programmed sampler, another advantage of composite sampling follows from the fact that the sampler can operate for longer periods, without changing bottles, and thereby allows to sample larger and longer duration 
rain events (Harmel et al. 2003). The reported disadvantages of composite sampling of storm events are the risks of possible error estimates in load calculations and the lack of temporal data on the pollution distribution (Miller et al. 2000; King and Harmel 2003). For sampling small to intermediate snow piles, the composite sampling could be a good choice, but it is not recommended for sampling large snow storage sites, because it yields just average values, but would not detect the presence of hot spots at snow storage sites.

Analysis of water quality conditions in water bodies requires identification of sources of pollutants adversely impacting on such waters and the development of priorities for remedial action. Thus, prioritization of pollutants at individual sites is essential (Mayes et al. 2009) and provides valuable inputs to policy makers and practitioners in developing remedial plans of action (Eriksson et al. 2007; Lundy et al. 2012). Lundy et al. (2012) developed a strategy for risk prioritization of stormwater pollutants on the basis of sources. In our study, the ratio SPMC/GC was calculated for $\mathrm{Zn}, \mathrm{Cd}, \mathrm{Cu}, \mathrm{Pb}$, and $\mathrm{Ni}$ and was used for prioritizing pollutants. Based on the SPMC/ $\mathrm{GC}$ ratio, $\mathrm{Zn}$ was found to be the most environmentally significant pollutant for the Frihamnen receiving waters. Galfi et al. (2017) also reported that $\mathrm{Zn}$ is the major pollutant of concern in stormwater by analyzing stormwater quality, from four catchments with varying degrees of urban development, in Östersund, Sweden. Furthermore, $\mathrm{Zn}$ was included as a priority pollutant on the list of selected stormwater priority pollutants (SSPP) by Eriksson et al. (2007). While discussing the Frihamnen data, it should be recognized that in calculations of the SPMC/GC ratios, the guideline values from Gothenburg Municipality (Gothenburg Municipality 2013) were used, because no similar guidelines were available for the study area. Such a substitution brings some uncertainty into the analysis, recognizing that the Gothenburg guidelines for discharging stormwater effluents (as determined by the maximum event mean concentrations) into the receiving waters have been developed just for the Gothenburg Municipality in southern Sweden. Consequently, the use of these guidelines should serve as a trigger for conducting further investigations targeting the pollutants of concerns, and their sources, for the Frihamnen receiving waters.

The chemical status of all surface waters in Sweden is classified as "Good" or "Unsatisfactory" by assessing the levels of 45 priority substances in surface waters against the values in the Water Information System Sweden (VISS, Vatten Informations System Sverige) (HVMFS 2013:19 2016). The measured concentrations of anthracene (Ant, mean $146 \mu \mathrm{g} / \mathrm{kg}$ TS) in sediment samples from Lilla Värtan exceeded the guideline values $(24 \mu \mathrm{g} / \mathrm{kg}$ TS) for all seven samples collected between 2002 and 2013. However, Ant concentrations in the receiving waters (i.e., whole water samples) of Lilla Värtan did not exceed the guideline values suggested by the marine and water authority of Sweden (HVMFS 2018:17 2018). In our study, the concentrations of Ant were close to, or below, the reporting limit for all the snow piles studied. According to VISS, the ecological status of Lilla Värtan was classified as unsatisfactory based on three factors: the rate of eutrophication, environmental impacts by contaminants, and morphological and flow changes (HVMFS 2013:19 2016). The critical contaminants that led to this classification status were PCBs (polychlorinated biphenyls), $\mathrm{Cu}$, and $\mathrm{Zn}$. PCBs were not analyzed in this study, since their use and their products have been banned in Sweden from the 1970s (SFS 1985:837 1985). Cu and $\mathrm{Zn}$ were identified in our study as critical pollutants as well, using whole water samples. However, the assessment of VISS was based on the measurement of $\mathrm{Cu}$ in sediment samples and $\mathrm{Zn}$ in water samples from Lilla Värtan during 2009 to 2013.

$\mathrm{Zn}$ and $\mathrm{Cu}$ are of particular interest in this study since their concentrations exceeded the Gothenburg effluent guidelines. These metals are found in urban snow samples, mostly in the particulate fraction (Glenn and Sansalone 2002; Westerlund and Viklander 2011; Galfi et al. 2016). Source control or pollution prevention is an effective and relatively inexpensive solution to reduce pollution (Ports 2009; Marsalek and Viklander 2011) in this study area, since there is a space constraint to implement snowmelt treatment facilities, e.g., settling or bioretention, in the port catchment. To plan and implement source control measures for $\mathrm{Zn}$ and $\mathrm{Cu}$, a good understanding of their sources in snow is essential (Loganathan et al. 2013). Since the snow is cleared, piled, and disposed of within 2 days of snowfall (NIRAS Sweden AB 2016), it is likely that the main sources of pollutants in the studied snow samples are road sediments contributed by vehicular traffic and road attrition and traction agents used in road maintenance. The abrasives used to maintain traffic safety during winter months are sources of heavy metals in snow (Oberts 1986; Reinosdotter 2007). Thus, optimal 
applications of traction materials established by considering the level of service required and weather conditions could be one of the measures reducing the pollutants in snow. Another possibility would be to examine the feasibility of increasing the effectiveness of the existing sludge trap in the study area ((ACO NORDIC 2013b). Finally, if space allows, a unique facility for melting snow by seawater temperature in Oslo Harbor, Norway, may also offer some solutions. Snow is tipped into the melting plant, where it is mixed with seawater. The melting snow/water mixture is subject to sedimentation and filtration, before discharged into the sea (NCC 2013). This type of snow treatment would eliminate the need for space to store snow and would reduce the environmental impacts of snow dumping into the receiving waters. In any case, the knowledge of pollutants causing the highest levels of risk to the quality of the receiving water bodies is needed for developing sustainable snow management practices.

\section{Conclusions}

Pollutant loads in snow piles, serving for temporary storage $(<28 \mathrm{~h})$ of snow cleared from a port facility catchment, were studied, using the following snow quality parameters: TSS, conductivity, $\mathrm{Zn}, \mathrm{Cu}, \mathrm{Cd}, \mathrm{Cr}, \mathrm{Pb}, \mathrm{V}$, and 16 USEPA PAHs. For this purpose, the snow piles were sampled using a systematic 1-m square grid sampling, which produced more accurate pollutant loads than a single snow column sampling (i.e., a sample collected at a random point, through the full depth of the pile) or the composite sampling (two horizontally composed volumeproportional single column samples). Concentrations of the studied quality parameters widely varied within (coefficient of variation, $150 \%$ ), and among (by an order of magnitude), the individual piles. The mass load estimated from the preferred strategy of grid sampling, yielding 14 28 samples for individual piles, was termed the best estimate of mass load (BEML), which was then used to assess the performance of two other sampling strategies. In worst cases, loads calculated for single snow column sampling deviated from BEML by up to $400 \%$, and the loads for composition of point samples into two composite samples deviated from BEML by up to $50 \%$. However, the grid sampling design required the highest resources, and therefore, reducing the number of samples was addressed. The number of samples collected and their spatial distribution within the snow pile footprint were two major factors influencing the calculated pollutant loads. The results indicated that deviations of calculated pollutant loads from BEML decreased with the number of samples. The number of samples needed to estimate the pollutant loads within 50\% deviation from BEML increased with the size of the pile and non-uniformity of spatial pollutant distributions in piles; for the conditions studied, on average, 35$70 \%$ of all samples were needed to produce load estimates within $\pm 50 \%$ of BEML. In an environmental assessment, the ratio of measured pollutant concentrations to stormwater effluent guideline values indicated that $\mathrm{Zn}$ was the most critical parameter for the snow piles studied in Frihamnen (the average concentration measured in snow piles samples, $84 \mu \mathrm{g} / \mathrm{L}$ and the guideline concentration, $30 \mu \mathrm{g} / \mathrm{L}$ ). Detailed examination of the receiving water body at Frihamnen is needed to confirm whether $\mathrm{Zn}$ is indeed a critical parameter affecting the receiving water quality. The study results suggest that the assessment of quality of snow dumped into receiving waters and identification of site-specific critical pollutants is important for advancing the development of sustainable snow disposal practices.

Supplementary Information The online version contains supplementary material available at https://doi.org/10.1007/s11270021-05002-9.

Acknowledgements The authors gratefully acknowledge the Swedish Research Council Formas (Sustainable urban snow handling-2015-00120) and DRIZZLE Centre for Stormwater Management (Vinnova, Grant no. 2016-05176) for funding this study. The authors also wish to express their gratitude to the colleagues in the Urban Water Engineering group at Luleå University of Technology and the staff at Ports of Stockholm for field and laboratory assistance.

Author Contribution All authors contributed to the design of this study. Arya Vijayan performed collection of samples, laboratory analysis, statistical data analysis, and interpretation of the results. Arya Vijayan wrote the first draft of the manuscript. Helene Österlund, Jiri Marsalek, and Maria Viklander participated in the interpretation of results and contributed to drafting the final version of the manuscript. All authors read and approved the final manuscript.

Funding Open Access funding provided by Lulea University of Technology.

Open Access This article is licensed under a Creative Commons Attribution 4.0 International License, which permits use, sharing, adaptation, distribution and reproduction in any medium or format, as long as you give appropriate credit to the original author(s) and the source, provide a link to the Creative Commons licence, and 
indicate if changes were made. The images or other third party material in this article are included in the article's Creative Commons licence, unless indicated otherwise in a credit line to the material. If material is not included in the article's Creative Commons licence and your intended use is not permitted by statutory regulation or exceeds the permitted use, you will need to obtain permission directly from the copyright holder. To view a copy of this licence, visit http://creativecommons.org/licenses/by/4.0/.

\section{References}

ACO NORDIC (2013a) Stormpass CM Bypass well for oil separator for ground laying (Stormpass CM Bypassbrunn till oljeavskiljare för markförläggning, in Swedish). Available on-line at: http://www.aco-nordic.se/produkter/stormpass$\mathrm{cm}$ / (Accessed June 29, 2020).

ACO NORDIC (2013b) SLUDGETRAP C Sand/sludge separator for ground laying (SLUDGETRAP C Sand/slamavkiljare för markanläggning, in Swedish). Available on-line at: http://www.aco-nordic.se/produkter/sludgetrap-c/ (Accessed June 29, 2020).

ACO NORDIC (2018a) Oleopator C oil separator for ground laying (OLEOPATOR C Oljeavskiljare för markförläggning, in Swedish). Available on-line at: http://www.aco-nordic. se/produkter/oleopator-c/ (Accessed June 29, 2020).

ACO NORDIC (2018b) Oleosmart C oil separator with Split contraction unit for ground laying (OLEOSMART C Oljeavskiljare med Split Contraction-enhet för markförläggning, in Swedish). Available on-line at: http://www.aco-nordic. se/produkter/oleosmart-c/ (Accessed June 29, 2020).

ADEC (2006) Evaluation of snow disposal into near shore marine environments (Contract 18-9001-12). Alaska Department of Environmental Conservation, Alaska. Available on-line at https://dec.alaska.gov/media/16083/adec-snow-disposalevaluation.pdf (Accessed June 02 ,2020).

Aziz, F., Syed, H., Naseem Malik, R., et al. (2014). Occurrence of polycyclic aromatic hydrocarbons in the Soan River, Pakistan: insights into distribution, composition, sources and ecological risk assessment. Ecotoxicology and Environmental Safety, 109, 77-84. https://doi.org/10.1016/j. ecoenv.2014.07.022.

Björklund, K., Strömvall, A.-M., \& Malmqvist, P.-A. (2011). Screening of organic contaminants in urban snow. Water Science and Technology, 64, 206-213. https://doi. org/10.2166/wst.2011.642.

Brewer, R., Peard, J., \& Heskett, M. (2017). A critical review of discrete soil sample data reliability: Part 1 - field study results. Soil and Sediment Contamination, 26, 1-22. https://doi. org/10.1080/15320383.2017.1244171.

City of Toronto Transportation Department. (2019). Winter maintenance program review. Available on-line at: https://www. toronto.ca/legdocs/mmis/2019/ie/bgrd/backgroundfile138573.pdf, Accessed 3 Sept 2020

Corsi, S. R., Graczyk, D. J., Geis, S. W., et al. (2010). A fresh look at road salt: aquatic toxicity and water-quality impacts on local, regional, and national scales. Environmental Science \& Technology, 44, 7376-7382. https://doi.org/10.1021/es101333u.
Directive 2008/105/EC (2008) Directive of the European parliament and of the council of 16 December 2008 on environmental quality standards in the field of water policy. Available on-line at: https://eur-lex.europa.eu/legalcontent/EN/TXT/PDF/?uri=CELEX:32008L0105\&from= EN (Accessed September 25, 2018).

Droste, R. L., \& Johnston, J. C. (1993). Urban snow dump quality and pollutant reduction in snowmelt by sedimentation. Canadian Journal of Civil Engineering, 20, 9-21. https://doi.org/10.1139/193-002.

Engelhard, C., De Toffol, S., Lek, I., et al. (2007). Environmental impacts of urban snow management - the alpine case study of Innsbruck. Sci Total Environ, 382, 286-294. https://doi. org/10.1016/j.scitotenv.2007.04.008.

Eriksson, E., Baun, A., Scholes, L., et al. (2007). Selected stormwater priority pollutants - a European perspective. Sci Total Environ, 383, 41-51. https://doi.org/10.1016/j. scitotenv.2007.05.028.

Exall, K., Marsalek, J., Rochfort, Q., Kydd, S. (2011). Chloride transport and related processes at a municipal snow storage and disposal site. Water Quality Research Journal of Canada, 46, 148-156. https://doi.org/10.2166 /wqrjc.2011.023

Fabietti, G., Biasioli, M., Barberis, R., \& Ajmone-Marsan, F. (2010). Soil contamination by organic and inorganic pollutants at the regional scale: the case of Piedmont, Italy. Journal of Soils and Sediments, 10, 290-300. https://doi.org/10.1007 /s11368-009-0114-9.

Galfi, H., Österlund, H., Marsalek, J., Viklander, M. (2016). Indicator bacteria and associated water quality constituents in stormwater and snowmelt from four urban catchments. Journal of Hydrology, 539, 125-140. https://doi. org/10.1016/j.jhydrol.2016.05.006

Galfi, H., Österlund, H., Marsalek, J., \& Viklander, M. (2017). Mineral and anthropogenic Indicator inorganics in urban stormwater and snowmelt runoff: sources and mobility patterns. Water, Air, and Soil Pollution, 228. https://doi. org/10.1007/s11270-017-3438-X.

Glenn, D. W., \& Sansalone, J. J. (2002). Accretion and partitioning of heavy metals associated with snow exposed to urban traffic and winter storm maintenance activities. II. $J$ Environ Eng, 128, 167-185. https://doi.org/10.1061 /(ASCE)0733-9372(2002)128:2(167).

Gothenburg Municipality (2013) The Environment Department's guidelines and guideline values for discharges of polluted water to receiving waters and stormwater (Miljöförvaltningens riktlinjer och riktvärden för utsläpp av förorenat vatten till recipient och dagvatten, in Swedish). Gothenberg. Available on-line at: https://goteborg.se/wps/wcm/connect/fee9bd22-ed19-43ed907c-14fc36d3da16/N800_R_2013_10.pdf?MOD=AJPERES (Accessed May 16, 2020).

Gunawardena, J., Ziyath, A. M., Egodawatta, P., et al. (2015). Sources and transport pathways of common heavy metals to urban road surfaces. Ecological Engineering, 77, 98-102. https://doi.org/10.1016/j.ecoleng.2015.01.023.

Guo, W., He, M., Yang, Z., et al. (2009). Distribution, partitioning and sources of polycyclic aromatic hydrocarbons in Daliao River water system in dry season, China. Journal of Hazardous Materials, 164, 1379-1385. https://doi. org/10.1016/j.jhazmat.2008.09.083. 
Gupta, A. K., Gupta, S. K., Patil, R. S. (2005). Environmental management plan for port and harbour projects. Clean Technologies and Environmental Policy, 7, 133-141. https://doi.org/10.1007/s10098-004-0266-7

Henriksen A, Dale T, Haugen S (1974) Melting of polluted snow in thermostated lysimeter (Smeltning av forurenset snö $\mathrm{i}$ termostater lysimeter, in Norwegian). Oslo.

Hjortenkrans, D., Bergb“ack, B. O., Bergb"ack, B., \& Aggerud, A. H. (2006). New metal emission patterns in road traffic environments. Environmental Monitoring and Assessment, 117, 85-98. https://doi.org/10.1007/s10661-006-7706-2.

Hjortenkrans, D. S. T., Bergbäck, B. G., \& Häggerud, A. V. (2008). Transversal immission patterns and leachability of heavy metals in road side soils. Journal of Environmental Monitoring, 10, 739-746. https://doi.org/10.1039/b804634d.

HongWei, Z., PengDa, C., BaoChang, Z., \& DaoZeng, W. (2014). The mechanisms of contaminants release due to incipient motion at sediment-water interface. Sci China-Phys Mech Astron, 57, 1563-1568. https://doi.org/10.1007/s11433-013-5255-6.

HVMFS 2013:19 (2016) Environmental pollutants in water - classification of surface water status (Miljögifter i vatten klassificering av ytvattenstatus, in Swedish). Havs och Vatten myndigheten Gothenburg. Available on-line at: https://www. havochvatten.se/download/18.6d9c45e9158fa37fe9f57c25 /1482143211383/vagledn-miljogiftsklassning-hvmfs201319. pdf (Accessed June 08, 2020).

HVMFS 2018:17 (2018) Regulations of the marine and water authority on classification and environmental quality standards of surface waters (Havs- och vattenmyndighetens föreskrifter om klassificering och miljökvalitetsnormer avseende ytvatten, in Swedish). Havs och Vattenmyndigheten, Gothenburg Available on-line at: https://www.havochvatten. se/download/18.73800df2167072a23ab1d6f8/1542205426676 /HVMFS\%202018-17-ev.pdf (Accessed June 09, 2020).

Jervis, R. E., Landsberger, S., Lecomte, R., et al. (1982). Determination of trace pollutants in urban snow using PIXE techniques. Nucl Instruments Methods, 193, 323-329. https://doi.org/10.1016/0029-554X(82)90718-2.

Jirka GH, Doneker RL, Hinton SW, Biswas H (1996) User's manual for cormix: a hydrodynamic mixing zone model and decision support system for pollutant discharges into surface waters. Washington DC. Available on-line at: https://www.epa.gov/sites/production/files/2015-10 /documents/cormix-users 0.pdf (accessed may 12, 2020).

Johannessen, M., \& Henriksen, A. (1978). Chemistry of snow meltwater: Changes in concentration during melting. Water Resources Research, 14, 615-619. https://doi.org/10.1029 /WR014i004p00615.

King, K. W., \& Harmel, R. D. (2003). Considerations in selecting a water quality sampling strategy. Trans am Soc Agric Eng, 46, 63-73. https://doi.org/10.13031/2013.7391.

Kuoppamäki, K., Setälä, H., Rantalainen, A.-L., \& Kotze, D. J. (2014). Urban snow indicates pollution originating from road traffic. Environmental Pollution, 195, 56-63. https://doi. org/10.1016/j.envpol.2014.08.019.

Lindqvist H (2019) Regulations on laying snow on land (Regler kring uppläggning av snö på land - Naturvårdsverket, in Swedish). Available on-line at : https://www.naturvardsverket.se/Stod-imiljoarbetet/Vagledningar/Avfall/Upplaggning-av-sno-/ (Accessed May 25, 2020).
Lobkina, V. A., Muzychenko, A. A., \& Mikhalev, M. V. (2019). Soil chemistry dynamics at snow disposal sites in YuzhnoSakhalinsk. Earth's Cryosph Sci J, XXIII, 50-55. https://doi. org/10.21782/EC2541-9994-2019-4(50-55).

Loganathan, P., Vigneswaran, S., \& Kandasamy, J. (2013). Roaddeposited sediment pollutants: a critical review of their characteristics, source, apportionment, and management. Critical Reviews in Environmental Science and Technology, 43, 1315-1348. https://doi.org/10.1080/10643389.2011.644222.

Lovison, G., Gore, S. D., \& Patil, G. P. (1994). Design and analysis of composite sampling procedures: a review. Handb Stat, 12, 103-166. https://doi.org/10.1016/S01697161(05)80006-9.

Lundy, L., Ellis, J. B., \& Revitt, D. M. (2012). Risk prioritisation of stormwater pollutant sources. Water Research. https://doi. org/10.1016/j.watres.2011.10.039.

Malherbe, L. (2002). Designing a contaminated soil sampling strategy for human health risk assessment. Accreditation and Quality Assurance, 7, 189-194. https://doi.org/10.1007 /s00769-002-0464-0.

Malmquist, P.-A. (1984). Environmental effects of snow disposal in Sweden (pp. 74-81). In: Minimizing the Environmental Impact of the Disposal of Snow from Urban Areas.

Malmquist, P. A. (1978). Atmospheric fallout and street cleaning: effects on urban storm water and snow. Prog Water Technol, 10, 495-505. https://doi.org/10.1016/B978-0-08-0229393.50043-X.

Marsalek, J., Oberts, G., Exall, K., \& Viklander, M. (2003). Review of operation of urban drainage systems in cold weather: water quality considerations. Water Science and Technology, 48, 1120. https://doi.org/10.2166/wst.2003.0481.

Marsalek, J., Viklander, M. (2011). Controlling contaminants in urban stormwater: linking environmental science and policy. In: Lundqvist J (ed) On the water front: selections from the 2010 World Water Week in Stockholm. Stockholm International Water Institute (SIWI), Stockholm, pp 100108. Available on-line at:http://hispagua.cedex. e s/s i t e s/d e fau $1 \mathrm{t} / \mathrm{fil}$ e s/ h i s p a g a documento/OntheWaterFront2010_FINAL.pdf\#page $=100$. Accessed 06 Jun 2020

Mayes, W. M., Johnston, D., Potter, H. A. B., \& Jarvis, A. P. (2009). A national strategy for identification, prioritisation and management of pollution from abandoned non-coal mine sites in England and Wales. I. Methodology development and initial results. Sci Total Environ, 407, 5435-5447. https://doi. org/10.1016/j.scitotenv.2009.06.019.

McLeod, S. (2019). What does a box plot tell you? Simply psychology. https://www.simplypsychology.org/boxplots. html. Accessed 14 May 2020

Meyer, T., Lei, Y. D., Ibrahim, M., \& Wania, F. (2009). Organic contaminant release from melting snow. 1. Influence of chemical partitioning. Environmental Science \& Technology, 43, 657662. https://doi.org/10.1021/es8020217.

Miller, P. S., Engel, B. A., \& Mohtar, R. H. (2000). Sampling theory and mass load estimation from watershed water quality data. In 2000 ASAE annual Intenational meeting (pp. 671-683). Engineering Solutions for a New Century: Technical Papers.

Minigazimov, N., Khaidarshina, E., Abdrahmanov, R., et al. (2019). City snow dumps of a large industrial centre as a source of surface water pollution (on the example of Ufa 
City). Asian J Water, Environ Pollut, 16, 51-58. https://doi. org/10.3233/AJW190019.

Moghadas, S., Paus, K. H., Muthanna, T. M., et al. (2015). Accumulation of traffic-related trace metals in urban winterlong roadside snowbanks. Water, Air, \& Soil Pollution, 226, 404. https://doi.org/10.1007/s11270-015-2660-7.

NCC (2013) Snow melting plant processes (process för snösmältningsanläggning NCC, in Swedish). Available onlline at: https://www.ncc.se/link/0b366115180e419e88f48 b2766706fd6.aspx (Accessed June 20, 2020).

NIRAS Sweden AB (2016) Snow management control program port areas in Stockholm (kontrollprogram för snöhantering hamnområden i Stockholm, in Swedish). Stockholm.

Nordqvist K, Viklander M, Westerlund C, Marsalek J (2011) Measuring solids concentrations in urban runoff: methods of analysis. In: 12th International Conference on Urban Drainage, Porto Alegre/Brazil, 11-16 September 2011.

Novotny, V., Muehring, D., Zitomer, D. H., et al. (1998). Cyanide and metal pollution by urban snowmelt: impact of deicing compounds. Water Science and Technology, 38, 223-230. https://doi.org/10.1016/S0273-1223(98)00753-7.

Novotny, V., Smith, D. W., Kuemmel, D. A., et al. (1999). Urban and Highway Snowmelt: Minimizing the Impact on Receiving Water. Alexandria VA

Oberts, G., Marsalek, J., \& Viklander, M. (2000). Review of water quality impacts of winter operation of urban drainage. Water Qual Res J Canada, 35, 781-808. https://doi.org/10.2166 /wqrj.2000.042.

Oberts, G. L. (1986). Pollutants associated with sand and salt applied to roads in Minnesota. Journal of the American Water Resources Association, 22, 479-483. https://doi. org/10.1111/j.1752-1688.1986.tb01903.x.

Ports MA (2009) Source control: the solution to stormwater pollution. In: Proceedings of World Environmental and Water Resources Congress 2009 - World Environmental and Water Resources Congress 2009: Great Rivers. pp 782-790.

Harmel, R. D., King, K. W., \& Slade, R. M. (2003). Automated storm water sampling on small watersheds. Appl Eng Agric, 19, 667-674. https://doi.org/10.13031/2013.15662.

Reinosdotter, K. (2007). Sustainable snow handling - doctoral thesis. Luleå University of Technology.

Reinosdotter, K., \& Viklander, M. (2005). A comparison of snow quality in two Swedish municipalities - Luleå and Sundsvall. Water, Air, and Soil Pollution, 167, 3-16. https://doi. org/10.1007/s11270-005-8635-3.

Reinosdotter, K., \& Viklander, M. (2006). Handling of urban snow with regard to snow quality. Journal of Environmental Engineering, 132, 271-278. https://doi. org/10.1061/(ASCE)0733-9372(2006)132:2(271).

Reinosdotter, K., Viklander, M., \& Malmqvist, P. A. (2006). Polycyclic aromatic hydrocarbons and metals in snow along a highway. Water Science and Technology, 54, 195-203. https://doi.org/10.2166/wst.2006.600.

Schondorf, T., Herrmann, R. (1987). Transport and Chemodynamics of Organic Micropollutants and Ions during Snowmelt. Nordi, 18, 259-278. https://doi.org/10.2166 /nh.1987.0019

Semadeni-Davies, A.F. (1999). Snow heterogeneity in Lulea, Sweden. Urban Water, 1, 39-47. https://doi.org/10.1016 /S1462-0758(99)00003-5
SFS 1985:837 (1985) Ordinance on PCBs (Förordning (1985:837) om PCB m. m.- In Swedish). Stockholm. Available online at $>$ https://www.riksdagen.se/sv/dokumentlagar/dokument/svensk-forfattningssamling/forordning1985837-om-pcb-m-m_sfs-1985-837 (Accessed August 28, 2020).

Sillanpää, N., \& Koivusalo, H. (2013). Catchment-scale evaluation of pollution potential of urban snow at two residential catchments in southern Finland. Water Science and Technology, 68, 2164-2170. https://doi.org/10.2166 /wst.2013.466.

Siudek, P., Frankowski, M., \& Siepak, J. (2015). Trace element distribution in the snow cover from an urban area in Central Poland. Environmental Monitoring and Assessment, 187, 225. https://doi.org/10.1007/s10661-015-4446-1.

SMHI. (2020). Download meteorological observations (Ladda ner meteorologiska observationer, in Swedish). https://www. smhi.se/data/meteorologi/ladda-ner-meteorologiskaobservationer/\#param=precipitation24HourSum,stations= all,stationid=98230. Accessed 23 Jun 2020

SS EN 872 (2005) SS-EN 872 Water quality - determination of suspended solids - methods by filtration through glass fibre filters, SIS. Swedish standard institute, 2005.

Swedish EPA 5050 (2000) Environmental quality criteria: lakes and watercourses. Stockholm Available on-line at: ftp://priede.bf.lu.lv/grozs/HidroBiologjijas/LAKE_ watercourses.pdf ().

Trahan N. A., Peterson C. M. (2007). Factors impacting the health of roadside vegetation. No. CDOT-DTD-R-2005-12. Colorado Department of Transportation Research Branch, Greeley. Available on-line at: https://www.codot. gov/programs/research/pdfs/2005/vegetation.pdf. Accessed 22 Mar 2019

USEPA. (1983). Results of the nationwide urban runoff program. D.C. Available on-line at: Washington https://nepis.epa. gov/Exe/ZyPURL.cgi?Dockey=9100QOIJ.TXT (Accessed May 21, 2020).

USEPA (2002) Guidance on choosing a sampling design for environmental data collection. Washington DC Available on-line at: http:/www.epa.gov/sites/production/files/201506/documents/g5s-final.pdf (Accessed April 17, 2020).

Vallero, D. A. (2013). Measurements in environmental engineering. In M. Kutz (Ed.), Handbook of measurement in science and engineering. Wiley, Hoboken, New Jersey.

Vijayan, A., Österlund, H., Marsalek, J., Viklander, M. (2019). Laboratory Melting of Late-Winter Urban Snow Samples: The Magnitude and Dynamics of Releases of Heavy Metals and PAHs. Water, Air, \& Soil Pollution, 230, 182. https://doi. org/10.1007/s11270-019-4201-2

Viklander, M. (1996). Urban snow deposits-pathways of pollutants. Science of the Total Environment, 189/190, 379-384. https://doi.org/10.1016/0048-9697(96)05234-5

Viklander M (1997) Snow quality in urban areas- PhD Thesis. Luleå University of Technology.

Viklander, M. (1999). Substances in urban snow. A comparison of the contamination of snow in different parts of the city of Luleå, Sweden. Water, Air, Soil Pollut, 114, 377-394. https://doi.org/10.1023/A:1005121116829.

Viklander, M. (1998). Snow quality in the city of Lulea, Sweden time variation of lead, zinc, copper and phosphorus. Sci Total 
Environ, 216, 103-112. https://doi.org/10.1016/s0048-9697 (98)00148-x.

VISS EU_CD: SE658352-163189 (2019) Lilla Värtan - water information system for Sweden (Lilla Värtan VattenInformationsSystem för Sverige, in Swedish). Stockholm. Available on-line at: https://viss.lansstyrelsen. se/Waters.aspx?waterMSCD=WA46408217

Westerlund C, Viklander M, Nordqvist K, et al (2011) Particle pathways during urban snowmelt and mass balance of selected pollutants. In: 12th International Conference on Urban Drainage. Porto Alegre/Brazil.
Westerlund, C., \& Viklander, M. (2011). Pollutant release from a disturbed urban snowpack in northern Sweden. Water Qual Res J Canada, 46, 98-109. https://doi.org/10.2166 /wqrjc.2011.025.

Publisher's Note Springer Nature remains neutral with regard to jurisdictional claims in published maps and institutional affiliations. 